\title{
Are Populists Insecure About Themselves or About Their Country? Political Attitudes and Economic Perceptions
}

\author{
Barry Watson $^{1}$ (D) Stephen Law $^{2} \cdot$ Lars Osberg $^{3}$
}

Accepted: 21 July 2021 / Published online: 4 August 2021

(c) The Author(s), under exclusive licence to Springer Nature B.V. 2021

\begin{abstract}
We investigate whether greater economic insecurity increases distrust in government and fosters authoritarian politics. Using the 2016 American National Election Studies dataset, we build on the literature regarding "egotropic" and "sociotropic" economic concerns to distinguish between "micro" insecurity (perceived insecurity regarding the individual's own personal economic well-being), and "macro" insecurity (negative expectations concerning the macro economy). Our results suggest micro insecurity is not significantly correlated with attitudinal differences, but macro-level insecurity is associated with increased levels of political distrust, accompanied by greater authoritarianism. Greater macro-level insecurity is also associated with more negative feelings toward "out-groups" (e.g. Muslims, the LGBTQ+ community, feminists, immigrants) and was a key predictor in reduced affinity for Hillary Clinton and the rise in support for Donald Trump. Results are robust to controls for political affiliation and aggregate macroeconomic indicators, suggesting that rising levels of income inequality and weakening social safety nets increase political polarization and encourage xenophobia, racism, and homophobia.
\end{abstract}

Keywords Economic insecurity $\cdot$ Authoritarianism $\cdot$ Xenophobia $\cdot$ Racism $\cdot$ Homophobia Elections

Barry Watson

bwatson@unb.ca

Stephen Law

slaw@mta.ca

Lars Osberg

Lars.Osberg@dal.ca

1 University of New Brunswick, Saint John, Canada

2 Mount Allison University, Sackville, Canada

3 Dalhousie University, Halifax, Canada 


\section{Introduction}

American politics, in recent years, has seen massive shifts. A particularly sharp contrast in the rhetoric of recent elections was that between the theme of "hope" in Obama's 2008 US Federal Election campaign and the very different slogan of Donald Trump in 2016 to "make America great again". Trump's appeal to traditionalism was, as Jacobson (2017) notes, in glaring contrast to an ideology of openness and quite different from the historic dichotomy of "left" versus "right", which had previously centered on normative beliefs regarding the appropriate size of government. ${ }^{1}$ Indeed, given that Democratic administrations constructed most of the American social safety net while Republicans had historically advocated policies of austerity and shrinkage of the welfare state, a conundrum of the 2016 US election was why so many disadvantaged Americans, who would benefit from greater social protection, voted for the Republican candidate.

Obama came to power during a severe recession and great insecurity. While his theme of hope embodied a denial of fear of the future, it was also a promise of change. Was the 2016 election outcome, in part, driven by a sense of betrayal at the failure of the Obama administration to deliver on those promises of change? ${ }^{2}$ Could it be that the "Make America Great Again" (MAGA) movement should be read as a different, less optimistic, type of response to the same basic problem - that the voters who want to restore "Greatness" (by voting for Trump) really want to restore the sort of society in which people "like me" can be secure in prosperity and social status?

A central theme of discussion regarding the 2016 US election results focuses on debates between the "left behind" ${ }^{3}$ and "deplorables"4 perspectives, which have differing implications. Although not mutually exclusive, the "left behind" argument emphasizes the frustrations of low-educated workers (particularly in "Rust Belt" regions) with American public policy (non)response to the long-term decline in their real wages and job security along with the trend to an increasingly unequal society. The implication is that greater economic security and rising real wages might reduce the MAGA appeal - and public policy changes, like a greater monetary policy emphasis on full employment, can address such issues. However, the "deplorables" perspective, in stressing the long historic roots of the resentments of advantaged groups (e.g., white males) at perceived relative gains of those historically disadvantaged by race, ethnicity or gender, is more pessimistic about policy options. It is not entirely clear how public policy can directly eliminate embedded racist, xenophobic, misogynist or homophobic attitudes - but the public policy option of

\footnotetext{
1 Mudde (2007) argues that the populist right appeals to nationalistic pride, stressing traditional values and order, by using images of a mythic glorious past. Moreover, Grossmann and Thaler (2018) note that those most averse to change, believing that such changes have undermined traditional American values, were the most likely to support Donald Trump.

${ }^{2}$ Koehler and Gershoff (2003) suggest individuals are sensitive to situations where a violation of duty is perceived, while Bohnet and Zeckhauser (2004) find the harm from betrayal exceeds the monetary costs of the event, leading to betrayal aversion. Moreover, Tella and Rotemberg (2018) note that such aversion gives rise to a preference for populist regimes.

3 See: Galston (2017); Ulrich-Schad and Duncan (2018).

4 The origin of this term can be found in Hillary Clinton's September 9th, 2016 speech: “To just be grossly generalistic, you can put half of Trump supporters into what I call the basket of deplorables, right? Racist, sexist, homophobic, xenophobic, Islamophobic, you name it." Research supporting this conjecture includes: Schaffner et al. (2018) and Mutz (2018).
} 
pandering to such beliefs by ignoring the restricted advancement of disadvantaged groups is deeply unattractive.

This paper tests a hypothesis which has elements in common with both approaches: that rising levels of economic insecurity underlie both increased resentment of "out-groups" and greater distrust of the political elites who supported macroeconomic policies (such as free trade agreements) which are widely seen as causing these insecurities. We hypothesize that these greater resentments and this increased distrust have produced a populist response characterized by authoritarian politics. Using a rich set of outcomes within the most recent wave (2016) of the American National Election Studies (ANES), our paper therefore extends the literature on the implications of economic insecurity regarding political distrust.

What evidence is there that greater economic insecurity might shift attitudes? As Hacker (2006) notes in The Great Risk Shift, there has been a general increase in economic insecurity in the US, dating back to the 1980s. Historically, when it was common for firms to offer long-term employment contracts and defined benefit pension plans, employers shouldered much of the economic risk associated with market dynamics. Such institutional arrangements have shrunk dramatically in prevalence, offloading risk to labour. Anderson (2018) also argues that since the 1970s, declining unionization, policies favouring capital (i.e., increasing its share of national income), and rising earnings inequality have favored the rise of populist parties and resentment of so-called "out-groups". Similarly, McCarty et al. (2006) find that income inequality and political polarization have increased in unison since the 1970s. Moreover, Inglehart and Norris (2017) note that increased insecurity promotes in-group solidarity along with the rejection of outsiders and a rising authoritarianism response. Using the 2008 wave of the ANES survey, Wroe (2016) finds that economic insecurity is associated with a reduction in political trust - suggesting an increased level of disdain for those in power. Likewise, Wroe (2014) notes that job insecurity predicts a lower level of trust in political institutions and the democratic process.

In suggesting a link between "authoritarianism" and "insecurity", we should define both terms. Linz (1964) suggests that authoritarianism encompasses political regimes characterized by: (i) limited political pluralism, (ii) a lack of guiding ideology, (iii) no political mobilization, and (iv) a leader exercising power within poorly defined limits. Similarly, Gasiorowski (1990) defines authoritarianism as a regime "in which a strong, charismatic, manipulative leader rules through a coalition involving key lower class groups" (p. 115) and Przeworski (1991) note it rests "mainly on lies, fear, or economic prosperity" (p. 58). In the seminal work on this topic, Adorno et al. (1950) point to increased aggression toward "out-groups" and more widespread prevalence of prejudice and anti-democratic behaviour as indicators of a political landscape more prone to give rise to an authoritarian regime. Guiso et al. (2017) suggest that right-wing populist political parties position themselves as champions of "the people" against the elite, while pandering to the fears of their supporters and advocating short-term protectionist strategies.

Economic insecurity has been defined by Osberg (1998) as: "the anxiety produced by a lack of economic safety, i.e., by an inability to obtain protection against subjectively significant potential economic loss" (p. 23). Greater anxiety can stem from either a greater probability of an adverse event or greater loss from a given event (or both). Greater incidence and longer duration of unemployment both imply more economic insecurity - e.g., recessions increase insecurity because they produce an increased probability of job loss and a greater cost of job loss as a result of longer unemployment spells. Economic insecurity differs conceptually from "risk" or "volatility" in earnings, which include the chances of upside as well as downside future events. Although past events are the only evidence that 
is available to people in forming their expectations, ${ }^{5}$ economic insecurity is driven by fears about the future - i.e., by future downside hazards (Osberg 2015).

But exactly how might worries about the economic future affect voting intentions? The political science literature on the impact of economic concerns on voting behavior has drawn a distinction between egotropic and sociotropic evaluations - i.e., in the context of economic insecurity, between "micro-level" insecurity about one's personal situation and "macro-level" insecurity driven by perceptions of the economy. ${ }^{6}$ Lockerbie (2006) has argued that: "voters look at what is in their wallet, untangle what is the government's responsibility and what is others' responsibility, and vote on the basis of what is in their wallet (or not there) that is attributed to the government" (p. 194). The empirical survey article of Lewis-Beck and tegmaier (2013) concludes that: "generally speaking, the economic vote, at the micro- or macro-levels, has statistical and substantive significance in democratic political systems" (p. 381) and "Clearly, sociotropic evaluations overwhelm egotropic ones. The relatively strong impact of sociotropic retrospective evaluations seems equally clear" (p. 370). ${ }^{7}$

The underlying motivations for sociotropic voting and political preference have been debated. It is possible that when questions are phrased in "macro" terms, it may be psychologically easier for respondents to blame "the government" or "the economy" than to call into question their individual capabilities or prior decisions. ${ }^{8}$ Perhaps self-interested respondents recognize that many policy outcomes that are good for the country (like low unemployment) are also good for them. Or respondents could be, to some degree, altruistic and community-minded.

Whatever the motivation for sociotropic retrospective evaluations, what defines the "community" over which they are considered? In modern societies, there are many different levels of identity and a crucial question is whether economic trends, like greater insecurity, are driving an increasingly intolerant and xenophobic narrowing of self-identification. Steenvoorden and Wright (2019) have argued that "uncertainty increases the need for people to seek reassurance from the collectivity, either via group identification per se or the adoption of group-derived values and norms" (p. 8) and that "sociotropic uncertainty mitigates multiple identification. Which types of sociotropic uncertainty are likely to matter? ... political distrust, negative economic expectations and societal pessimism" (p. 9). They conclude: "sociotropic uncertainty mitigates multiple political identification, because it makes people seek certainty by embracing simplified identity profiles that more easily mitigate uncertainty. Political distrust, negative economic expectations and societal pessimism all go hand-in-hand with selective (rather than multiple) political identification" (p. 21).

\footnotetext{
5 The Economic Security Index of Hacker et al. (2014) reflects the share of working age individuals in the relevant sample who have experienced a large $(>25 \%)$ decline in real household income from the previous year (while lacking adequate wealth buffers). Similarly, Bossert et al. (2019) use the changes in household nominal equivalized income from the previous period, over a five-year interval.

6 An example of an individual's egotropic concerns might be whether their current employer will fire them while a sociotropic concern might be whether their employer will lay off workers due to a recession.

7 This finding extends back to Kinder and Kiewiet (1981). See also Inglehart and Norris (2016).

${ }^{8}$ For example, an individual's anxieties about the future value of their stock portfolio might come either from worries about trends in the prices of the stocks they already own or from worries about whether there will be a general downturn in the market. Vocalizing anxieties as being about "the market" avoids any necessity for the respondent to confront an implication that they may have made a bad decision in buying those particular stocks.
} 
Consistent with that, Mughan et al. (2004) suggest that sociotropic job insecurity had a larger impact than egotropic insecurity in increasing the probability of voting for the populist party, One Nation Party, in Australia. Moreover, Mughan and Lacy (2002) find that poor evaluations of sociotropic job insecurity were predictive of Americans rejecting both major candidates in the 1996 federal election. This is a particularly striking result as it occurred during an era of robust economic growth, not unlike that of 2016.

In this paper, using principal component analysis, we derive two indices pertaining to predictors of insecurity using a series of questions differentiating between egotropic or "micro" level insecurity about one's personal situation and sociotropic or "macro" level insecurity driven by perceptions of the economy. Based on our reading of the literature, we hypothesize that:

H1 Differences in the level of economic uncertainty/insecurity are significant determinants of differences in political attitudes;

$\mathrm{H} 2$ "Macro" or sociotropic insecurity concerns dominate "micro" or egotropic issues;

H3 Greater economic insecurity is associated with increased support for authoritarianism, a higher likelihood of xenophobic, racist, homophobic and sexist views, and ultimately more support for Donald Trump;

H4 These results are not exclusive to a particular political affiliation and are not just a proxy for objective macroeconomic conditions;

H5 Retrospective sociotropic economic security survey questions are likely to be particularly significant correlates of attitudinal differences.

Using the 2016 wave of the ANES, our results confirm these hypotheses. Although increased micro-level insecurity is associated with more distrust, there does not appear to be a consistent association with any of our other dependent variables. In particular, confirming $\mathrm{H} 2$, the impact of our predictor concerning microeconomic insecurity is, for the most part, statistically insignificant at conventional levels. Even in the rare times we can reject the null, the magnitude of association is much smaller than the impact of macroeconomic insecurity.

Our results suggest, as $\mathrm{H} 3$ predicts, that a higher level of macro-level insecurity not only predicts more distrust, but is associated with increased support for authoritarianism, a higher likelihood of xenophobic, racist, homophobic, and sexist views, and ultimately more support for Donald Trump. Deeper examination supports H4 and H5, suggesting these results are not exclusive to a particular political affiliation and are primarily driven by a dismal subjective view of the past and present economic state - i.e., subjective perceptions which are not just a proxy for objective macroeconomic conditions. As an extension of our findings, we also uncover support for Mutz's (2018) argument of a "status threat" given that US-born, White, heterosexual males who observe the macro economy as poor are most likely to display these tendencies.

In Sect. 2, we discuss the dataset and our methods, while Sect. 3 presents our results. Section 4 provides a battery of robustness checks and finally, Sect. 5 discusses the findings and their implications. 


\section{Data and Methods}

\subsection{Dataset: American National Election Studies}

This study uses the 2016 wave of the ANES survey, which seeks to "inform explanations of election outcomes by providing data that support rich hypothesis testing, maximize methodological excellence, measure many variables, and promote comparisons across people, contexts, and time." Since 1948, a new cross-sectional survey has been released every federal election year. The 2016 wave collected data on 4,271 respondents of voting age via face-to-face interviewing and internet surveys. Moreover, given the stratified sampling design, provided sample weights are applied throughout our analysis.

Our sample is the 1020 males and 1003 females in the 2016 wave with some labour force attachment. Specifically, the respondent must have been able to reflect on their level of job security, or concern over finding employment if jobless. Americans over 65 are the main group excluded by this restriction but although they are a politically important demographic, the predictability and inflation indexation of their Social Security pensions imply that the economic insecurity experienced by the retired population is driven by uncertainty about future expenditure needs (e.g. for home care) and uncertainty about future financial returns on private savings (if any). The drivers of economic insecurity for the working age population are very different. While our results cannot therefore necessarily be extrapolated to the entire US electorate, our sample is representative of roughly four-fifths of the adult population. ${ }^{9}$

Respondents were interviewed twice: (i) just prior to the election (between September 7 and November 7) and (ii) shortly after the election (between November 9 and January 8). With the exception of distrust, the outcome variables were observed after the election, while the micro- and macroeconomic variables were collected prior to the election. This timing helps assure, without fully obviating all concerns related to consistency bias, hindsight bias, or simultaneity bias, that views on authoritarianism, out-groups, and political party support were not revised to fit any newly-chosen political attitudes. ${ }^{10}$

\subsection{Dependent Variables}

Using the ANES, we can examine a rich set of attitudes concerning distrust of government, authoritarianism, xenophobia, racism, homophobia, feminism, and religion - and whether certain correlates of such attitudes also predict support for the federal election candidates Donald Trump and Hillary Clinton. Indeed, as depicted in "Appendix" Table 6, more government distrust, more authoritarianism, and less tolerant attitudes toward socalled "out-groups" are all quite positively correlated with support for Donald Trump while being negatively correlated with support for Hillary Clinton. But is economic insecurity an underlying driver of these "regrettable" outcome variables, and if so, is it the micro- or macro-level which matters most?

\footnotetext{
9 See: Howden and Meyer (2011).

10 As pointed out by Gillitzer and Prasad (2018), "precise timing of the shifts in sentiment at changes of government indicates that the variation reflects voting intentions affecting economic beliefs rather than perceptions of current economic conditions affecting voting behavior" (p. 236).
} 
Our indicator of distrust of government is based on the question: "How often can you trust the federal government in Washington to do what is right?". Responses are scored ranging in value from [1] "always" to [5] "never". The well-validated ${ }^{11}$ authoritarianism index is based on responses regarding the importance of a series of child traits. Respondents were asked which child traits are more important: Independence [0] or Self-Respect [2]; Curiosity [0] or Good Manners [2]; Self-Reliance [0] or Obedience [2]; and Considerate [0] or Well-Behaved [2]. The points regarding each option are in square brackets and if the respondent believed both choices were important, a value of [1] is assigned. Summation of the point values from the four questions yields a scale ranging from 0 to 8 , with higher values implying more support for authoritarianism.

Xenophobic attitudes are picked up by three questions about: (i) immigration levels, (ii) America's culture being harmed by immigrants, and (iii) immigrants being bad for the US economy. Each variable is measured on a 5-point scale, increasing in negative views of immigration. The first variable ranges from "increased a lot" to "decreased a lot", with the latter two ranging from "disagree strongly" to "agree strongly".

Our indicators of attitudes toward racism, homophobia, feminism and religion are all based on "feeling thermometers" calibrating the respondent's view of Blacks, Hispanics, and the Black Lives Matter Movement, feelings on Gays, Lesbians and Transgender people, opinions on Feminism, and feelings toward Jews and Muslims. Responses range from 0 to 100 , where 100 means the respondent felt very favourable about those in question, 50 indicates indifference, and 0 represents unfavourable feelings. Feeling thermometers are also applied to opinions of the 2016 political candidates, assessing both Donald Trump and Hillary Clinton on a 100-point scale.

\subsection{Economic Insecurity}

In this study, we want to distinguish between predictors of individual-level anxieties and worries about macro-level risk. Our predictors of egotropic or "micro-level" insecurity include questions on whether the respondent, at the time of survey, believed they personally: (i) are worse off than 12 months ago, (ii) will be worse off in 12 months, and (iii) are job insecure if employed, or worried about finding a job if unemployed. Predictors of sociotropic or "macro-level" insecurity are based on whether the respondent, in 2016, believed the economy: (i) is worse off than 12 months ago, (ii) will be worse in 12 months, and (iii) is currently bad. Each predictor is evaluated on a 5-point scale, increasing in agreement with these descriptions of the economy. ${ }^{12}$

Since each question predicts an aspect of economic insecurity about possible negative events, thus contributing to some facet of undesirable risk $(R)$, we extract the first principal component from our respective micro- and macro-level variables to derive two synthetic predictor variables for economic insecurity, ${ }^{13}$ such that:

\footnotetext{
11 See: Feldman and Stenner (1997); Stenner (2005); Hetherington and Weiler (2009); Hetherington and Suhay (2011).

12 Our use of predictors of economic insecurity can be seen as similar to the use of self-perceived health status as an outcome variable in health economics, since self-perceived health is not a measure of "health" (itself a multifaceted concept) or a physical or physician-generated diagnostic measure of health, rather it is a predictor of health.

13 As presented in "Appendix" Table 7, only the first component has a significant eigenvalue (i.e., in excess of 1), which captures the component's variance relative to the variance of the included variables. Unsurprisingly then, in both instances, the first component explains over 50 percent of the variance of the variables.
} 


$$
\begin{aligned}
& E I(\text { Micro })=\sum_{i=1}^{3} B_{i} R_{i} \\
& E I(\text { Macro })=\sum_{j=1}^{3} B_{j} R_{j}
\end{aligned}
$$

where in each instance, the terms $B_{1}, B_{2}, B_{3}$ are chosen to maximize the variance in $E I(\cdot)$ subject to the restriction: $\sum B^{2}=1$. These two variables capture this latent-class concept of undesirable risk from both the micro and macro perspectives. For intuition purposes, each index is standardized to have a mean of 0 and standard deviation of 1 .

\subsection{Additional Explanatory Variables}

In the United States, political party identification has become a significant predictor of many attitudes and perceptions, including some only tenuously related to traditional political concerns (e.g., opinions about the seriousness of COVID-19). ${ }^{14}$ Attitudes toward the incumbent government may therefore jointly determine both voting intentions and perceived economic insecurity. Specifically, sociotropic factors may be endogenously determined as rationalizations of political sentiment (Kinder and Kiewiet 1979; Tormos 2019). We therefore control for party identification by including Republican and Independent dummy variables (Democrat being the reference category) and also analyze attitudes across affiliations separately. Moreover, to examine whether there is sufficient variation in our macroeconomic insecurity variable, such that its influence can be detected even among strong political identifiers, "Appendix" Fig. 7 presents two kernel density plots of macro insecurity attitudes among the top quartile of Democrat and Republican party supporters (using the ANES 100-point feeling thermometers). Notably, there is considerable macro insecurity variation even among the most ardent Democrat and Republican supporters, which reassures us that our macro insecurity index is not merely repurposed partisanship. ${ }^{15}$

Additionally, we control for a set of socio-economic variables which include education (equal to one if the respondent had a high school education or less; zero otherwise) and income. Within the dataset, the income variable consists of 28 categories, with the final option top-coded at " $\$ 250,000$ or more". With the exception of the top-coded category, we derive a dollar measure of income by computing the mid-point of each category. Since the Pareto distribution has been repeatedly found to provide a good fit in estimation of the top tail of the income distribution, income for those in the top-coded category is derived assuming that the expected value $(y)$ for this category is:

$$
y=\frac{\alpha}{\alpha-1} \times 250,000
$$

Footnote 13 (continued)

Furthermore, as presented in "Appendix" Table 7, all included variables tend be quite positively correlated with the first components.

14 See: Van Green and Tyson (2020).

15 To quantify this degree of variance, we compute the coefficient of variation for each sub-sample. For the Democrat sample, the value is 1.66 and for Republican supporters, it is 2.92 . Thus, in both instances, the standard deviation exceeds the mean. 
where $\alpha$ is the Pareto shape parameter. Assuming that the distribution above the lower threshold of " $\$ 175,000-\$ 249,999 "$ is Pareto, we use the quantile method as illustrated in Quandt (1966) to determine the shape parameter:

$$
\alpha=\ln \left(\frac{X_{175}}{X_{250}}\right) / \ln \left(\frac{Y_{250}}{Y_{175}}\right)
$$

where $X_{175}$ and $X_{250}$ capture the number of respondents at or above the second highest and highest income thresholds respectively, and $Y$ equals those income values. This imputation results in an income value of about $\$ 472,150$ for the highest income bracket and is in line with the Saez (2000) finding that the adjustment factor, $\frac{\alpha}{\alpha-1}$, is approximately equal to 2 at the top of the US income distribution. ${ }^{16}$ Our income variable is then specified in log terms.

As well, socio-demographic variables capturing age, and a set of dummy variables representing the respondent being, at the time of survey, a born-again Christian, visible minority, immigrant, along with being single, divorced, or widowed (marriage being the reference category) are included. Finally, we incorporate a dummy variable for state-level government which can test for other political attitudes such as "anti-incumbent" effects or "balancing-of-power" effects.

\subsection{Econometric Specification}

Regressions with non-categorical dependent variables (authoritarianism and the variables on a 0-100 scale) are run using ordinary least squares while regressions with categorical outcomes (the distrust and xenophobia variables) are run using an ordered probit specification. For the latter, average marginal effects are presented and discussed in terms of the likelihood of being in the most distrustful and most anti-immigration categories. Thus, we run the following regressions, separately for males and females:

$$
y_{i}=\alpha_{0}+\beta_{1} E I(\text { Micro })_{i}^{z}+\beta_{1} E I(\text { Macro })_{i}^{z}+P_{i}^{\prime} \gamma+S_{i}^{\prime} \delta+\text { Gov }_{i}^{\prime} \epsilon+v_{i}
$$

where $y$ equals the outcome for individual $i, E I(\cdot)^{z}$ represents the standardized economic insecurity index, $P$ is a set of political identification variables, $S$ captures the socio-economic and demographic controls, Gov captures whether the state governor, in 2016, was a Democrat or otherwise, and $v$ is the error term.

\section{Results}

\subsection{Descriptive Statistics}

Figures 1, 2, 3 present the frequencies for each micro-level insecurity categorical variable. Evaluations of their own household's financial position, compared to 12 months prior, were symmetric around the modal response for which almost half of male respondents and 41 percent of female respondents said things were the same. Regarding the future, almost 50 percent also expected their financial position to stay the same, with a tendency to optimism

\footnotetext{
${ }^{16}$ Using an alternative method illustrated by Armour et al. (2016), results in a slightly higher value for the top category at almost $\$ 509,000$ - however, both approaches produce virtually identical regression results.
} 
that it would likely be "somewhat better" and less than 5 percent expected it to be "much worse". Roughly 50 percent of the sample were "not at all" worried about the risk of job loss (or the prospect of finding a job if already jobless) with just over 20 percent being "a little concerned".

Respondents were not as positive about the macro economy, as depicted in Figs. 4, 5, 6. About 25 percent of males and 30 percent of females felt the economy had gotten "somewhat worse" or "much worse" over the past 12 months and over 30 percent viewed the current economy as "bad", which exceeds the cumulative number of individuals who reported it to be either "good" or "very good". However, more individuals agreed that the economy would get "much" or "somewhat" better than worse (women being a bit more optimistic), with over 50 percent believing that economic conditions would stay the same.

As Table 1 reports, many respondents were not overwhelmingly trustful of the federal government to do what is "right" -the average distrust score was 3.5, which falls between "about half of the time" [3] and "some of the time" [4]. In general, however, a notable feature of the distribution of attitudes is their dispersion. For example, the mean score of authoritarianism, was about 4.3 on the 8 -point scale, but the standard deviation was 2.6. In terms of immigration, on the 5-point scales, men and women had average response values in the vicinity of 2.5 , suggesting a fairly neutral stance, but with a standard deviation of just over 1 . Warmer views regarding visible minorities were slightly higher among women (about 71 versus 67 points regarding Blacks and Hispanics respectively), but standard deviations were virtually identical (21 points). Although the average female opinion regarding the Black Lives Matter movement was just over the lukewarm threshold at about 56, while the male result was slightly below lukewarm at about 46, the standard deviation in both cases was about 32. Men and women also differed in attitudes toward the LGBTQ+ community and Feminists: women had more positive feelings with average scores of 63 for the Transgender community, 68 for Gays and Lesbians, and 62 for Feminists, which were about 10 points higher than their male counterparts. However, these differences are not even close to statistically significant, since the standard deviations were at least 26 points in all cases. The same is true for views of religion, such that positive attitudes toward Muslims and Jews were slightly higher among women, but the standard deviations were once again roughly the same.

Although it would appear that there were gender differences in average feelings toward Hillary Clinton, since the mean female response was a lukewarm 51 and the average male response was 40, the standard deviation was roughly the same for both genders (about 33-34 points). Similarly, while men, on average, had a view of Trump that was about 45 points (a bit below the neutral level of 50) and the perspective of women was much lower at about 35 points, this difference is less than half the standard deviation (35 points). Clearly, there is plenty of variation in attitudes to be explained.

\subsection{Regression Results}

Table 2 presents our key regression results concerning the relationship between economic insecurity and: distrust and authoritarianism, along with attitudes regarding immigration, race, sexual orientation, feminism, religion, and the 2016 US federal election candidates. For brevity purposes, only the results concerning the micro- and macro-level insecurity variables are reported in Table 2, with a full set of estimates presented in "Appendix" Tables 8, 9, 10, 11, 12, 13, 14. There is a clear theme: controlling for other variables, our 
predictor of macro-level economic insecurity matters, but the predictor of micro-level economic insecurity does not. ${ }^{17,18}$

For example, a one standard deviation increase in macro-level economic insecurity is robustly associated with about a 5 percentage point rise in the likelihood of "never" trusting the federal government, while the reduction in trust given a rise in micro-level insecurity is much smaller in magnitude and only marginally statistically significant (i.e., at the 10 percent level). However, of all our results, this is the only instance where we find that household ("micro") insecurity has a statistically significant impact, and its magnitude is much smaller than that of macro-level insecurity.

Concerning authoritarianism, those with a relatively poor perception of the macro economy (i.e., one standard deviation above the mean), are expected to have a 0.40 (males) and 0.34 (female) point higher score on this 8-point scale. Similarly, micro-level economic vulnerability is not a significant correlate of xenophobia but macro-insecure males are about 9 percentage points more likely, and females about 6 percentage points more likely, to "agree strongly" with the belief that immigration numbers should be "decreased a lot" and about 2-3 percentage points more likely to strongly agree with the statements of immigrants being harmful to America's culture and being bad for the economy.

One standard deviation more macroeconomic insecurity is associated with about a 3-point decrease in positive attitudes toward the Black and Hispanic populations, for both men and women. However, for men, one standard deviation greater macro-insecurity is associated with an 8-point decline in support for Black Lives Matter, while the female result is a 5-point reduction. Concerning the LGBTQ+ community, results indicate that a one standard deviation increase in macro-level insecurity is associated with about a 3-point decline in approval of the Gay/Lesbian and Transgender communities, for both men and women. Macro-economically insecure men tend to have more negative views about feminists than similarly insecure women (the decrease for men is almost 5 points, but only about 2.6 for women). Religion results indicate that more macro-level insecurity negatively impacts views of Muslims with those exposed to such vulnerability being associated with a 6-point decrease in feelings toward this group. The result regarding Jews is not as strong, with insecure men predicted to have a 2.5 -point reduction in their attitude toward those of this faith; for females, results are statistically insignificant.

Politically, a key variable is whether an individual preferred Clinton or Trump. Our results indicate that micro insecurity is statistically insignificant as a determinant of support for either candidate. However, a one standard deviation rise in macroeconomic insecurity is strongly associated with positive attitudes towards Trump (about 10 points for men and 7 points for women) and negative attitudes towards Hillary Clinton (about 9 points for men and 11 points for women), after controlling for party affiliation, education, born-again

\footnotetext{
17 We also tested three alternative micro-level insecurity derivations, including: a Mincer earnings equation, along with a prediction of income volatility (i.e., both [1] the portion of earnings unexplained by observable factors and [2] observed negative deviations relative to predicted income). We also tested the impact of [3] the individual's probability of experiencing a bout of joblessness, conditional on a set of observable factors. Such micro-level insecurity proxies do not predict the outcomes presented in Table 2 of this paper. For brevity purposes, only the principal component results are presented in this section. Estimates are available from the lead author on request.

${ }^{18}$ To assess the possible role of multicollinearity between our micro insecurity index and an individual's socioeconomic status, we also ran regressions omitting both income and education. The microeconomic insecurity index remained statistically insignificant across our set of outcomes, with the one exception that more microeconomic insecurity is associated with a small increase in authoritarianism among females.
} 
Table 1 Descriptive statistics-outcome variables

\begin{tabular}{|c|c|c|c|c|}
\hline & \multicolumn{2}{|l|}{ Males } & \multicolumn{2}{|c|}{ Females } \\
\hline & Mean & St. Dev. & Mean & St. Dev. \\
\hline Distrust & 3.53 & 0.88 & 3.52 & 0.85 \\
\hline Authoritarianism & 4.35 & 2.57 & 4.31 & 2.56 \\
\hline \multicolumn{5}{|l|}{ Xenophobia } \\
\hline Immigration level should be decreased & 2.63 & 1.16 & 2.63 & 1.11 \\
\hline Immigration harms American culture & 2.44 & 1.17 & 2.31 & 1.14 \\
\hline Immigration is Bad for the Economy & 2.53 & 1.14 & 2.57 & 1.09 \\
\hline \multicolumn{5}{|l|}{ Racism } \\
\hline Blacks & 66.84 & 21.30 & 71.62 & 21.31 \\
\hline Hispanics & 66.93 & 21.22 & 70.52 & 21.64 \\
\hline Black lives matter & 45.72 & 32.61 & 56.06 & 31.86 \\
\hline \multicolumn{5}{|l|}{ Homophobia and female empowerment } \\
\hline Gays and lesbians & 58.24 & 28.74 & 68.12 & 26.53 \\
\hline Transgenders & 53.03 & 27.56 & 62.81 & 27.32 \\
\hline Feminists & 51.77 & 25.97 & 61.61 & 26.10 \\
\hline \multicolumn{5}{|l|}{ Religion } \\
\hline Jews & 67.61 & 22.36 & 72.30 & 22.10 \\
\hline Muslims & 52.66 & 25.88 & 59.80 & 26.13 \\
\hline \multicolumn{5}{|l|}{ Political support } \\
\hline Hillary Clinton & 39.68 & 32.78 & 50.59 & 34.11 \\
\hline Donald Trump & 44.66 & 34.57 & 35.28 & 34.69 \\
\hline
\end{tabular}

Dataset: 2016 American National Election Studies. Descriptive statistics are based on 1020 male observations and 1003 female observations. Distrust is measured on a 5-point scale ranging from a belief that Washington will "always" do what is right [1] to "never [5]. Authoritarianism is captured using an 8-point index, increasing in authoritative support. Xenophobia variables are all on a 5-point scale, increasing in negative views concerning immigrants. The remaining variables are all measured on a 100-point scale known as feeling thermometers, each is increasing in support for that particular variable

fundamentalism and race, each of which are strongly significant correlates. As one might expect, the dummy variable for self-reported Republicans has clearly the largest impact on pro-Trump/anti-Clinton attitudes. This parallels the work by Margalit (2019), who suggests that while factors such as rising economic insecurity may have tipped the balance in favour of Trump, the largest predictor of support for the Republican nominee was partisanship. However, the magnitude of impact of more macroeconomic insecurity is large relative to several other variables often identified as important in the literature - macro insecurity has a roughly similar size impact as that of visible minority status (although in reverse direction of association), and is greater than that of born-again fundamentalism, and in the case of men, having high school education or less.

\subsection{Perception Versus Reality}

A natural question to ask is whether or not the influence on attitudes of variables measuring subjective macroeconomic insecurity are really picking up the impact of objective reality. We therefore test whether our macroeconomic insecurity results disappear when we 
Table 2 Micro and macro insecurity regression results

\begin{tabular}{|c|c|c|c|c|}
\hline & \multicolumn{2}{|l|}{ Males } & \multicolumn{2}{|l|}{ Females } \\
\hline & Micro index & Macro index & Micro index & Macro index \\
\hline \multirow[t]{2}{*}{ Distrust } & $0.015^{*}$ & $0.054^{* * *}$ & $0.015^{*}$ & $0.048^{* * *}$ \\
\hline & $(0.008)$ & $(0.011)$ & $(0.008)$ & $(0.009)$ \\
\hline \multirow[t]{2}{*}{ Authoritarianism } & -0.019 & $0.397^{* * *}$ & 0.106 & $0.342^{* * *}$ \\
\hline & $(0.102)$ & $(0.105)$ & $(0.094)$ & $(0.101)$ \\
\hline \multicolumn{5}{|c|}{ Xenophobia; Immigration } \\
\hline \multirow[t]{2}{*}{ Decreased a Lot } & -0.006 & $0.088^{* * *}$ & -0.003 & $0.058^{* * *}$ \\
\hline & $(0.012)$ & $(0.015)$ & $(0.011)$ & $(0.013)$ \\
\hline \multirow[t]{2}{*}{ Does cultural harm } & 0.002 & $0.023^{* * *}$ & -0.001 & $0.017^{* * *}$ \\
\hline & $(0.005)$ & $(0.006)$ & $(0.004)$ & $(0.005)$ \\
\hline \multirow[t]{2}{*}{ Is bad for econ. } & -0.000 & $0.035^{* * *}$ & 0.001 & $0.030^{* * * *}$ \\
\hline & $(0.005)$ & $(0.007)$ & $(0.005)$ & $(0.006)$ \\
\hline \multicolumn{5}{|l|}{ Racism } \\
\hline \multirow[t]{2}{*}{ Blacks } & 0.165 & $-3.543^{* * *}$ & 0.523 & $-2.452^{* *}$ \\
\hline & $(0.961)$ & $(1.050)$ & $(0.877)$ & $(0.967)$ \\
\hline \multirow[t]{2}{*}{ Hispanics } & 0.048 & $-3.389^{* * *}$ & -0.571 & $-3.173^{* * *}$ \\
\hline & $(0.978)$ & $(1.019)$ & $(0.924)$ & $(0.969)$ \\
\hline \multirow[t]{2}{*}{ Black lives matter } & -1.628 & $-8.109^{* * *}$ & -0.303 & $-4.910^{* * *}$ \\
\hline & $(1.468)$ & $(1.350)$ & $(1.136)$ & $(1.137)$ \\
\hline \multicolumn{5}{|c|}{ Homophobia and female empowerment } \\
\hline \multirow[t]{2}{*}{ Gays and lesbians } & -1.258 & $-3.404^{* * *}$ & -0.475 & $-3.296^{* * *}$ \\
\hline & $(1.175)$ & $(1.313)$ & $(1.087)$ & $(1.172)$ \\
\hline \multirow[t]{2}{*}{ Transgender } & -0.390 & $-3.166^{* * *}$ & -0.581 & $-3.590^{* * *}$ \\
\hline & $(1.101)$ & $(1.221)$ & $(1.087)$ & $(1.180)$ \\
\hline \multirow[t]{2}{*}{ Feminism } & -0.0827 & $-4.898^{* * *}$ & -1.536 & $-2.640^{* *}$ \\
\hline & $(1.105)$ & $(1.183)$ & $(1.060)$ & $(1.156)$ \\
\hline \multicolumn{5}{|l|}{ Views on religion } \\
\hline \multirow[t]{2}{*}{ Jews } & 0.845 & $-2.525^{* *}$ & -1.429 & -1.221 \\
\hline & $(1.040)$ & $(1.010)$ & $(0.964)$ & $(1.048)$ \\
\hline \multirow[t]{2}{*}{ Muslims } & 0.085 & $-5.970^{* * *}$ & $-1.790^{*}$ & $-5.497^{* * *}$ \\
\hline & $(1.175)$ & $(1.161)$ & $(1.007)$ & $(1.197)$ \\
\hline \multicolumn{5}{|c|}{ Political candidate support } \\
\hline \multirow[t]{2}{*}{ Hillary Clinton } & -0.736 & $-9.312^{* * *}$ & -0.299 & $-10.884^{* * *}$ \\
\hline & $(1.104)$ & $(1.129)$ & $(1.133)$ & $(1.108)$ \\
\hline \multirow[t]{2}{*}{ Donald Trump } & -1.282 & $9.605^{* * *}$ & 0.064 & $7.400^{* * *}$ \\
\hline & $(1.326)$ & $(1.378)$ & $(1.262)$ & $(1.490)$ \\
\hline
\end{tabular}

$* * * p<0.01, * * p<0.05, * p<0.1$. Dataset: 2016 American National Election Studies. Results are based on 1020 male observations and 1003 female observations. Standard errors are in parentheses. Each row captures the respective micro and macroeconomic insecurity results for the outcome listed. Aside from the results pertaining to Distrust and Xenophobia, all estimates are derived using OLS, with the former determined using an ordinal probit specification where average marginal effects are presented. Additional controls include: political identification, income, education level, age, being "born-again", marital status, and whether governor is Republican or Democrat 
control for local unemployment rates. Employment data at the congressional district level, by level of education, was collected from the United States Census Bureau and merged with our dataset. Thus, for respondent $i$ from region $j$, we can control for the jobless rate of persons with a similar education, living in the same congressional district.

Results are presented in Table 3 and suggest that the inclusion of an objective macroeconomic variable has virtually no effect on our key results. Although the jobless rate has some independent impact, the magnitudes are much smaller than the subjective macroeconomic insecurity index. For instance, regarding authoritarianism, to equal a one standard deviation shock in subjective macroeconomic insecurity, the jobless rate would have to increase by almost 20 percentage points for males and by over 11 percentage points for females.

\subsection{Is a Political Identity Driving These Results?}

In a context as politically polarized as present-day America, ${ }^{19}$ it is also natural to ask if political identity may be driving these results. Thus far, we have reported the results of regressions run on all respondents, with dummy variables controlling for party affiliation. However, it is conceivable that the predictors of attitudes are structurally different among Democrats, Republicans, and Independents, if people have sorted into identity groups. We therefore run a separate set of regressions to test for structural differences, truncating the sample based on political identity. Table 4 reports, separately for males and females, whether the impact of macro insecurity differs among Democrats, Republicans and Independents. The first and fourth columns of results restrict the sample to those who report being Democrats, the second and fifth Republicans, and the third and sixth Independents.

Results are sometimes remarkably similar across political identities - notably in the large impact of macro insecurity on positive perceptions of Donald Trump among male Republicans, Democrats and Independents. The expected rise in support for Trump among those experiencing a one standard deviation increase in macro-level insecurity is about 9-10 points, regardless of affiliation. Similarly, for females experiencing such a negative shock, the predicted fall in support for Clinton is also quite consistent across affiliations, at about 10-11 points. Overall, the narrative remains consistent in terms of the impact of macroeconomic insecurity, especially with regard to feelings on immigration, the Black Lives Matter movement, and Muslims. While splitting the sample up by party affiliation and by gender implies a decrease in sample size, macro insecurity parameter estimates in Table 4 nonetheless generally have small standard errors, high levels of statistical significance and differ across party affiliation in magnitude but not in sign (with the exception of male and female Republican attitudes towards Hispanics and Jews and female Republicans feelings towards Blacks and Feminists).

\footnotetext{
19 Azzimonti (2018) finds that from 1981 to 2007, an index of reported political partisan conflict remained relatively stable but has risen substantially since the Great Recession. Moreover, Azzimonti posits that the uncertainty arising from this increase in political discord may partly explain the sluggish post-recession recovery.
} 


\subsection{US-Born White Males}

Gidron and Hall (2017) suggest that loss of social status among low-educated men has driven the rise in populist attitudes among this group. Moreover, Mutz (2018) argues that economic vulnerability (i.e., being "left behind") was not the driving force behind Trump's 2016 victory, suggesting instead that those who felt a "status threat" were most likely to support him. But the question remains whether the impact of economic insecurity remains important within the group Mutz is discussing: US-born White males who report being heterosexual. ${ }^{20}$ Since some respondents may have very positive (or very negative) views across all groups of people, and since this group of White males are presumably more apt to have positive views on White people (a feeling thermometer question also asked in the ANES), Table 5 reports attitude differences relative to how respondents felt about Whites.

Results suggest that among this group (heterosexual US-born White males), we almost always get the same basic result as in the case of the full sample: macro insecurity drives attitudes but micro insecurity does not. The exceptions, where micro insecurity also plays a role, are in attitudes regarding immigration doing cultural harm, Black Lives Matter, feminism, and Donald Trump. However, while these results have the same direction of association, coefficients are always much smaller in magnitude than the impacts of macro insecurity.

Compared to the full sample, the association between macroeconomic insecurity and authoritarianism is stronger: a one standard deviation increase in our index is associated with a 0.59 -point increase on the authoritarianism scale. Relative to the full sample of males, this group also seems to have slightly more xenophobic views when macro-economically stressed. Those experiencing a macroeconomic index shock are about 14 percentage points more likely to believe that immigrant levels should be "decreased a lot". Moreover, a one standard deviation increase in our macro insecurity index is associated with reduced feelings regarding visible minorities, the LGBTQ+ community, Feminists, and those from the Jewish and Muslim communities. In all cases, the magnitude represents a shift from the respondent's view of their own group, White people, and ranges in size from about 3 points regarding Jews and Hispanics to about 9 points regarding the Black Lives Matter movement. Finally, for this group of respondents, a one standard deviation increase in macrolevel insecurity is associated with a 13-point larger positive feeling toward Trump and a 10-point decline in feelings toward Clinton.

\section{Robustness Checks}

\subsection{Decomposition 1: Is There a Driving Force?}

Our principal component analysis approach is based on the idea that each question in the ANES captures an aspect of the more general issue of economic insecurity. However, it is possible that both our macro-level and micro-level results mask the importance of a particular component variable (or variables). This section therefore decomposes our indices such that each variable from Equations 1 and 2 is entered separately. Although each

\footnotetext{
${ }^{20}$ This represents a slight deviation from the Mutz definition of dominant status being a "White, Christian male".
} 
Table 3 Inclusion of jobless rate (JR) — adjusted for region and education

\begin{tabular}{|c|c|c|c|c|c|c|}
\hline & \multicolumn{3}{|l|}{ Males } & \multicolumn{3}{|l|}{ Females } \\
\hline & Micro & Macro & $\mathrm{JR}$ & Micro & Macro & JR \\
\hline \multirow[t]{2}{*}{ Distrust } & $0.015^{*}$ & $0.054^{* * *}$ & -0.000 & $0.016^{*}$ & $0.048^{* * *}$ & -0.000 \\
\hline & $(0.008)$ & $(0.011)$ & $(0.001)$ & $(0.008)$ & $(0.009)$ & $(0.001)$ \\
\hline \multirow[t]{2}{*}{ Authoritarianism } & -0.013 & $0.385^{* * *}$ & $0.020^{*}$ & 0.0689 & $0.361^{* * *}$ & $0.032^{* *}$ \\
\hline & $(0.104)$ & $(0.105)$ & $(0.011)$ & $(0.096)$ & $(0.102)$ & $(0.012)$ \\
\hline \multicolumn{7}{|c|}{ Xenophobia; Immigration } \\
\hline \multirow[t]{2}{*}{ Decreased a lot } & -0.006 & $0.088^{* * *}$ & -0.001 & -0.004 & $0.058^{* * *}$ & 0.001 \\
\hline & $(0.012)$ & $(0.015)$ & $(0.002)$ & $(0.011)$ & $(0.013)$ & $(0.002)$ \\
\hline \multirow[t]{2}{*}{ Does cultural harm } & 0.002 & $0.023^{* * *}$ & 0.001 & -0.002 & $0.017^{* * *}$ & 0.001 \\
\hline & $(0.005)$ & $(0.006)$ & $(0.001)$ & $(0.004)$ & $(0.005)$ & $(0.001)$ \\
\hline \multirow[t]{2}{*}{ Is bad for econ. } & 0.000 & $0.033^{* * *}$ & $0.002^{* *}$ & 0.002 & $0.030^{* * *}$ & -0.000 \\
\hline & $(0.005)$ & $(0.007)$ & $(0.001)$ & $(0.005)$ & $(0.006)$ & $(0.001)$ \\
\hline \multicolumn{7}{|l|}{ Racism } \\
\hline \multirow[t]{2}{*}{ Blacks } & 0.177 & $-3.568^{* * *}$ & 0.043 & 0.449 & $-2.415^{* *}$ & 0.063 \\
\hline & $(0.960)$ & $(1.045)$ & $(0.123)$ & $(0.881)$ & $(0.967)$ & $(0.111)$ \\
\hline \multirow[t]{2}{*}{ Hispanics } & 0.008 & $-3.305^{* * *}$ & -0.142 & -0.749 & $-3.084^{* * *}$ & 0.153 \\
\hline & $(0.991)$ & $(1.017)$ & $(0.116)$ & $(0.925)$ & $(0.973)$ & $(0.116)$ \\
\hline \multirow[t]{2}{*}{ Black lives matter } & -1.639 & $-8.086^{* * *}$ & -0.038 & -0.172 & $-4.975^{* * *}$ & -0.112 \\
\hline & $(1.479)$ & $(1.362)$ & $(0.161)$ & $(1.136)$ & $(1.132)$ & $(0.147)$ \\
\hline \multicolumn{7}{|c|}{ Homophobia and female empowerment } \\
\hline \multirow[t]{2}{*}{ Gays and lesbians } & -1.350 & $-3.212^{* *}$ & $-0.324^{* *}$ & -0.262 & $-3.403^{* * *}$ & -0.182 \\
\hline & $(1.195)$ & $(1.315)$ & $(0.155)$ & $(1.102)$ & $(1.179)$ & $(0.139)$ \\
\hline \multirow[t]{2}{*}{ Transgender } & -0.482 & $-2.973^{* *}$ & $-0.324^{* *}$ & -0.245 & $-3.759^{* * *}$ & $-0.289^{* *}$ \\
\hline & $(1.125)$ & $(1.224)$ & $(0.145)$ & $(1.096)$ & $(1.181)$ & $(0.139)$ \\
\hline \multirow[t]{2}{*}{ Feminism } & -0.148 & $-4.762^{* * *}$ & $-0.229^{*}$ & -1.132 & $-2.842^{* *}$ & $-0.347^{* *}$ \\
\hline & $(1.119)$ & $(1.190)$ & $(0.130)$ & $(1.078)$ & $(1.118)$ & $(0.156)$ \\
\hline \multicolumn{7}{|l|}{ Views on religion } \\
\hline \multirow[t]{2}{*}{ Jews } & 0.829 & $-2.491^{* *}$ & -0.058 & -1.097 & -1.387 & $-0.285^{* *}$ \\
\hline & $(1.046)$ & $(1.002)$ & $(0.142)$ & $(0.959)$ & $(1.050)$ & $(0.131)$ \\
\hline \multirow[t]{2}{*}{ Muslims } & 0.077 & $-5.952^{* * *}$ & -0.030 & -1.647 & $-5.569^{* * *}$ & -0.124 \\
\hline & $(1.184)$ & $(1.158)$ & $(0.147)$ & $(1.005)$ & $(1.195)$ & $(0.136)$ \\
\hline \multicolumn{7}{|c|}{ Political candidate support } \\
\hline \multirow[t]{2}{*}{ Hillary Clinton } & -0.763 & $-9.254^{* * *}$ & -0.096 & -0.285 & $-10.891^{* * *}$ & -0.012 \\
\hline & (1.105) & (1.129) & $(0.125)$ & (1.137) & (1.113) & $(0.128)$ \\
\hline \multirow[t]{2}{*}{ Donald Trump } & -1.183 & $9.400^{* * *}$ & $0.347^{* *}$ & -0.229 & $7.547^{* * *}$ & 0.252 \\
\hline & $(1.344)$ & (1.384) & $(0.175)$ & $(1.250)$ & $(1.426)$ & $(0.169)$ \\
\hline
\end{tabular}

$* * * p<0.01, * * p<0.05, * p<0.1$. Dataset: 2016 American National Election Studies. Results are based on 1020 male observations and 1003 female observations. Standard errors are in parentheses. Each row captures the respective micro and macroeconomic insecurity and jobless rate results for the outcome listed. Aside from the results pertaining to Distrust and Xenophobia, all estimates are derived using OLS, with the former determined using an ordinal probit specification where average marginal effects are presented. Additional controls include: political identification, income, education level, age, being "born-again", race, foreign/native born, marital status, and whether governor is Republican or Democrat 
Table 4 The impact of macro insecurity by party affiliation

\begin{tabular}{|c|c|c|c|c|c|c|}
\hline & \multicolumn{3}{|l|}{ Males } & \multicolumn{3}{|l|}{ Females } \\
\hline & Dem. & Rep. & Ind. & Dem. & Rep. & Ind. \\
\hline Distrust & $\begin{array}{l}0.042^{* * *} \\
(0.014)\end{array}$ & $\begin{array}{l}0.077^{* * *} \\
(0.021)\end{array}$ & $\begin{array}{l}0.044^{* *} \\
(0.019)\end{array}$ & $\begin{array}{l}0.042^{* * *} \\
(0.013)\end{array}$ & $\begin{array}{l}0.076^{* * *} \\
(0.023)\end{array}$ & $\begin{array}{l}0.047^{* * *} \\
(0.012)\end{array}$ \\
\hline Authoritarianism & $\begin{array}{l}0.480^{* *} \\
(0.202)\end{array}$ & $\begin{array}{l}0.305^{*} \\
(0.163)\end{array}$ & $\begin{array}{l}0.448^{* * *} \\
(0.168)\end{array}$ & $\begin{array}{l}0.297^{*} \\
(0.159)\end{array}$ & $\begin{array}{l}0.520^{* * *} \\
(0.182)\end{array}$ & $\begin{array}{l}0.251 \\
(0.186)\end{array}$ \\
\hline \multicolumn{7}{|c|}{ Xenophobia; Immigration } \\
\hline Decreased a lot & $\begin{array}{l}0.063^{* * *} \\
(0.019)\end{array}$ & $\begin{array}{l}0.113^{* * *} \\
(0.034)\end{array}$ & $\begin{array}{l}0.085^{* * *} \\
(0.023)\end{array}$ & $\begin{array}{l}0.029^{*} \\
(0.015)\end{array}$ & $\begin{array}{l}0.076^{* *} \\
(0.032)\end{array}$ & $\begin{array}{l}0.111^{* * *} \\
(0.022)\end{array}$ \\
\hline Does cultural harm & $\begin{array}{l}0.016^{*} \\
(0.009)\end{array}$ & $\begin{array}{l}0.032^{* * *} \\
(0.012)\end{array}$ & $\begin{array}{l}0.020^{* * *} \\
(0.007)\end{array}$ & $\begin{array}{l}0.006 \\
(0.006)\end{array}$ & $\begin{array}{l}0.034^{* * *} \\
(0.012)\end{array}$ & $\begin{array}{l}0.032^{* * *} \\
(0.010)\end{array}$ \\
\hline Is $\mathrm{Bad}$ for Econ. & $\begin{array}{l}0.013 * \\
(0.007)\end{array}$ & $\begin{array}{l}0.053^{* * *} \\
(0.016)\end{array}$ & $\begin{array}{l}0.038^{* * *} \\
(0.013)\end{array}$ & $\begin{array}{l}0.023^{* * *} \\
(0.008)\end{array}$ & $\begin{array}{l}0.044^{* * *} \\
(0.016)\end{array}$ & $\begin{array}{l}0.038^{* * *} \\
(0.011)\end{array}$ \\
\hline \multicolumn{7}{|l|}{ Racism } \\
\hline Blacks & $\begin{array}{l}-5.271^{* * *} \\
(2.013)\end{array}$ & $\begin{array}{l}-0.387 \\
(1.563)\end{array}$ & $\begin{array}{l}-3.831^{* *} \\
(1.745)\end{array}$ & $\begin{array}{l}-3.014^{* *} \\
(1.279)\end{array}$ & $\begin{array}{l}0.987 \\
(2.035)\end{array}$ & $\begin{array}{l}-4.870^{* *} \\
(1.902)\end{array}$ \\
\hline Hispanics & $\begin{array}{l}-6.917^{* * *} \\
(1.641)\end{array}$ & $\begin{array}{l}1.096 \\
(1.520)\end{array}$ & $\begin{array}{l}-3.774^{* *} \\
(1.706)\end{array}$ & $\begin{array}{l}-5.884^{* * *} \\
(1.278)\end{array}$ & $\begin{array}{l}1.295 \\
(1.940)\end{array}$ & $\begin{array}{l}-3.670^{*} \\
(1.918)\end{array}$ \\
\hline Black lives matter & $\begin{array}{l}-4.832^{*} \\
(2.624)\end{array}$ & $\begin{array}{l}-7.862^{\text {**** }} \\
(2.146)\end{array}$ & $\begin{array}{l}-10.430^{* * *} \\
(2.192)\end{array}$ & $\begin{array}{l}-4.542^{* * *} \\
(1.550)\end{array}$ & $\begin{array}{l}-2.311 \\
(2.865)\end{array}$ & $\begin{array}{l}-7.881^{* * *} \\
(2.059)\end{array}$ \\
\hline \multicolumn{7}{|c|}{ Homophobia and female empowerment } \\
\hline Gays and lesbians & $\begin{array}{l}-4.811^{*} \\
(2.669)\end{array}$ & $\begin{array}{l}-1.360 \\
(2.081)\end{array}$ & $\begin{array}{l}-4.527^{* *} \\
(2.190)\end{array}$ & $\begin{array}{l}-5.169^{\text {**** }} \\
(1.795)\end{array}$ & $\begin{array}{l}-0.992 \\
(2.100)\end{array}$ & $\begin{array}{l}-2.280 \\
(2.347)\end{array}$ \\
\hline Transgender & $\begin{array}{l}-3.387 \\
(2.525)\end{array}$ & $\begin{array}{l}-1.247 \\
(1.887)\end{array}$ & $\begin{array}{l}-4.754^{* *} \\
(1.934)\end{array}$ & $\begin{array}{l}-4.824^{\text {**** }} \\
(1.834)\end{array}$ & $\begin{array}{l}-1.205 \\
(2.170)\end{array}$ & $\begin{array}{l}-3.868^{*} \\
(2.022)\end{array}$ \\
\hline Feminism & $\begin{array}{l}-4.236^{*} \\
(2.179)\end{array}$ & $\begin{array}{l}-3.685^{*} \\
(1.944)\end{array}$ & $\begin{array}{l}-5.765^{* * *} \\
(1.834)\end{array}$ & $\begin{array}{l}-3.951^{* *} \\
(1.719)\end{array}$ & $\begin{array}{l}0.504 \\
(2.283)\end{array}$ & $\begin{array}{l}-3.333 \\
(2.250)\end{array}$ \\
\hline \multicolumn{7}{|l|}{ Views on religion } \\
\hline Jews & $\begin{array}{l}-2.553 \\
(2.017)\end{array}$ & $\begin{array}{l}0.706 \\
(1.560)\end{array}$ & $\begin{array}{l}-4.677^{* * *} \\
(1.687)\end{array}$ & $\begin{array}{l}-3.102^{* *} \\
(1.565)\end{array}$ & $\begin{array}{l}2.878 \\
(2.105)\end{array}$ & $\begin{array}{l}-2.291 \\
(1.919)\end{array}$ \\
\hline Muslims & $\begin{array}{l}-6.085^{* *} \\
(2.369)\end{array}$ & $\begin{array}{l}-5.494^{* * *} \\
(1.795)\end{array}$ & $\begin{array}{l}-6.296^{* * * *} \\
(1.765)\end{array}$ & $\begin{array}{l}-6.545^{\text {*** }} \\
(1.783)\end{array}$ & $\begin{array}{l}-1.535 \\
(2.482)\end{array}$ & $\begin{array}{l}-8.087^{\text {**** }} \\
(2.096)\end{array}$ \\
\hline \multicolumn{7}{|c|}{ Political candidate support } \\
\hline Hillary Clinton & $\begin{array}{l}-12.465^{\text {**** }} \\
(2.463)\end{array}$ & $\begin{array}{l}-5.883^{* * *} \\
(1.552)\end{array}$ & $\begin{array}{l}-10.525^{* * *} \\
(1.753)\end{array}$ & $\begin{array}{l}-11.463^{* * *} \\
(1.542)\end{array}$ & $\begin{array}{l}-10.416^{* * *} \\
(2.396)\end{array}$ & $\begin{array}{l}-9.903^{* * *} \\
(2.306)\end{array}$ \\
\hline Donald Trump & $\begin{array}{l}8.933^{* * *} \\
(2.756)\end{array}$ & $\begin{array}{l}9.836^{* * *} \\
(2.099)\end{array}$ & $\begin{array}{l}10.277^{* * *} \\
(2.206)\end{array}$ & $\begin{array}{l}4.964^{* *} \\
(2.419)\end{array}$ & $\begin{array}{l}7.915^{* * *} \\
(2.867)\end{array}$ & $\begin{array}{l}10.119^{* * *} \\
(2.318)\end{array}$ \\
\hline
\end{tabular}

$* * * p<0.01, * * p<0.05, * p<0.1$. Dataset: 2016 American National Election Studies. Results are based on 1020 male observations (299 Democrats, 346 Republicans, 375 Independents) and 1003 female observations (440 Democrats, 253 Republicans, 310 Independents). Standard errors are in parentheses. Each row captures the respective macroeconomic insecurity results for the outcome listed. Aside from the results pertaining to Distrust and Xenophobia, all estimates are derived using OLS, with the former determined using an ordinal probit specification where average marginal effects are presented. Additional controls include: the micro insecurity index, income, education level, age, being "born-again", race, foreign/native born, marital status, and whether governor is Republican or Democrat 
Table 5 US-born white males

\begin{tabular}{|c|c|c|}
\hline & Micro index & Macro index \\
\hline Distrust & $\begin{array}{l}0.014 \\
(0.014)\end{array}$ & $\begin{array}{l}0.088^{* * *} \\
(0.015)\end{array}$ \\
\hline Authoritarianism & $\begin{array}{l}0.084 \\
(0.127)\end{array}$ & $\begin{array}{l}0.586^{* * *} \\
(0.119)\end{array}$ \\
\hline \multicolumn{3}{|c|}{ Xenophobia; Immigration } \\
\hline Decreased a lot & $\begin{array}{l}-0.003 \\
(0.020)\end{array}$ & $\begin{array}{l}0.139^{* * *} \\
(0.020)\end{array}$ \\
\hline Does cultural harm & $\begin{array}{l}0.010^{*} \\
(0.006)\end{array}$ & $\begin{array}{l}0.031^{* * *} \\
(0.008)\end{array}$ \\
\hline Is bad for econ. & $\begin{array}{l}0.003 \\
(0.007)\end{array}$ & $\begin{array}{l}0.040^{* * *} \\
(0.010)\end{array}$ \\
\hline \multicolumn{3}{|l|}{ Racism } \\
\hline Blacks & $\begin{array}{l}-0.364 \\
(1.373)\end{array}$ & $\begin{array}{l}-3.684^{* *} \\
(1.544)\end{array}$ \\
\hline Hispanics & $\begin{array}{l}-1.177 \\
(1.500)\end{array}$ & $\begin{array}{l}-3.051^{* *} \\
(1.526)\end{array}$ \\
\hline Black lives matter & $\begin{array}{l}-2.746^{*} \\
(1.654)\end{array}$ & $\begin{array}{l}-9.039^{* * *} \\
(1.944)\end{array}$ \\
\hline \multicolumn{3}{|c|}{ Homophobia and female empowerment } \\
\hline Gays and lesbians & $\begin{array}{l}-1.965 \\
(1.948)\end{array}$ & $\begin{array}{l}-4.143^{* *} \\
(1.811)\end{array}$ \\
\hline Transgender & $\begin{array}{l}-0.794 \\
(1.769)\end{array}$ & $\begin{array}{l}-4.731^{* *} \\
(1.837)\end{array}$ \\
\hline Feminism & $\begin{array}{l}-2.664^{*} \\
(1.576)\end{array}$ & $\begin{array}{l}-5.675^{* * *} \\
(1.595)\end{array}$ \\
\hline \multicolumn{3}{|l|}{ Views on religion } \\
\hline Jews & $\begin{array}{l}0.082 \\
(1.521)\end{array}$ & $\begin{array}{l}-2.594^{*} \\
(1.522)\end{array}$ \\
\hline Muslims & $\begin{array}{l}-0.681 \\
(1.762)\end{array}$ & $\begin{array}{l}-7.009^{* * *} \\
(1.851)\end{array}$ \\
\hline \multicolumn{3}{|c|}{ Political candidate support } \\
\hline Hillary Clinton & $\begin{array}{l}-1.496 \\
(1.152)\end{array}$ & $\begin{array}{l}-10.198^{* * *} \\
(1.134)\end{array}$ \\
\hline Donald Trump & $\begin{array}{l}2.672^{* *} \\
(1.311)\end{array}$ & $\begin{array}{l}13.123^{* * *} \\
(1.446)\end{array}$ \\
\hline
\end{tabular}

$* * * p<0.01, * * p<0.05, * p<0.1$. Dataset: 2016 American National Election Studies. Results are based on 681 US-born, White, heterosexual males. Standard errors are in parentheses. Each row captures the respective micro and macroeconomic insecurity results for the outcome listed. Aside from the results pertaining to Distrust and Xenophobia, all estimates are derived using OLS, with the former determined using an ordinal probit specification where average marginal effects are presented. Additional controls include: political identification, income, education level, age, being "born-again", marital status, and whether governor is Republican or Democrat 


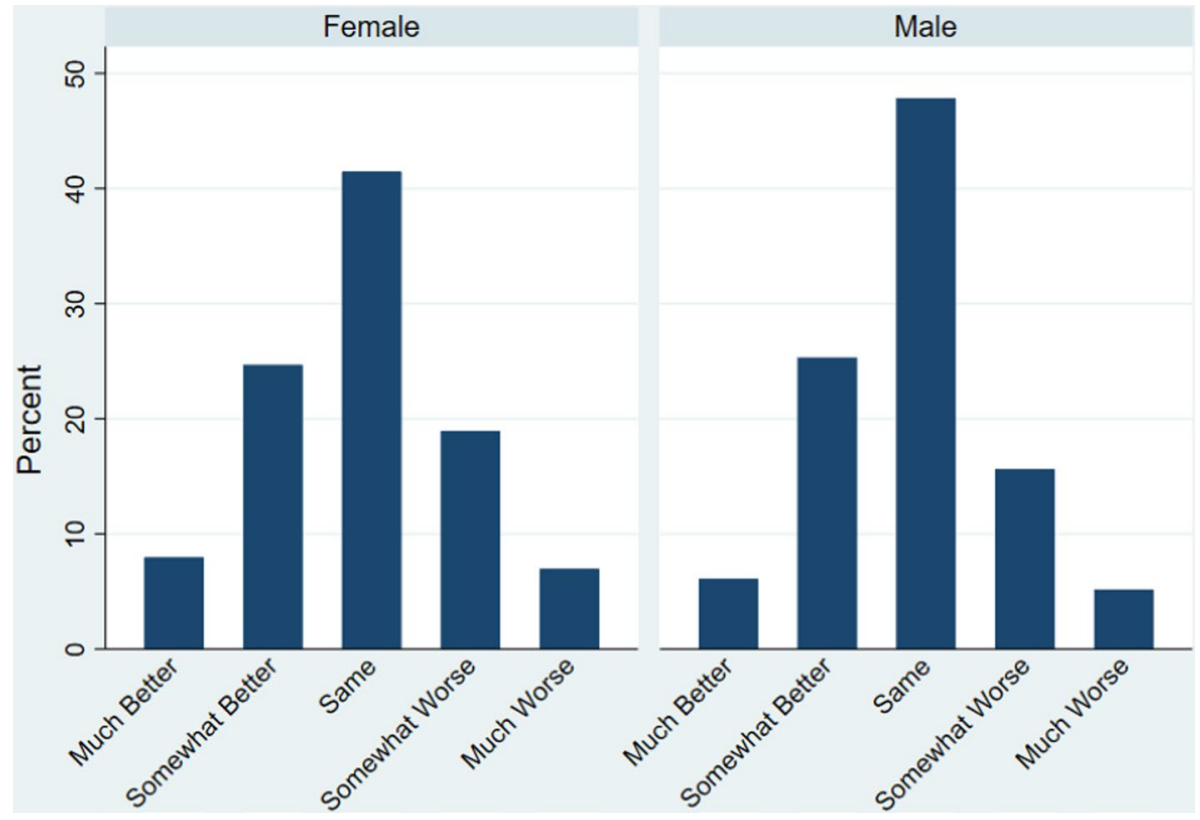

Fig. 1 Respondent's financial situation over past 12 months
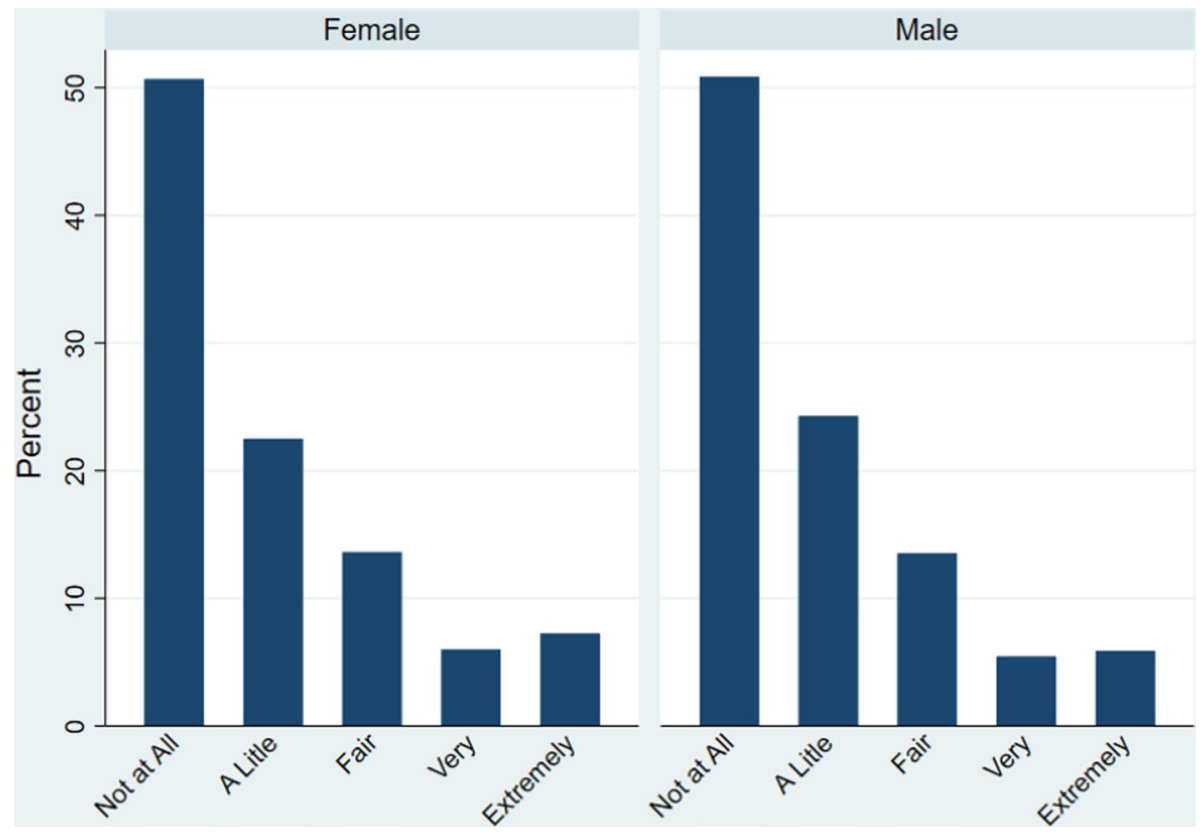

Fig. 2 Respondent is concerned about job security 


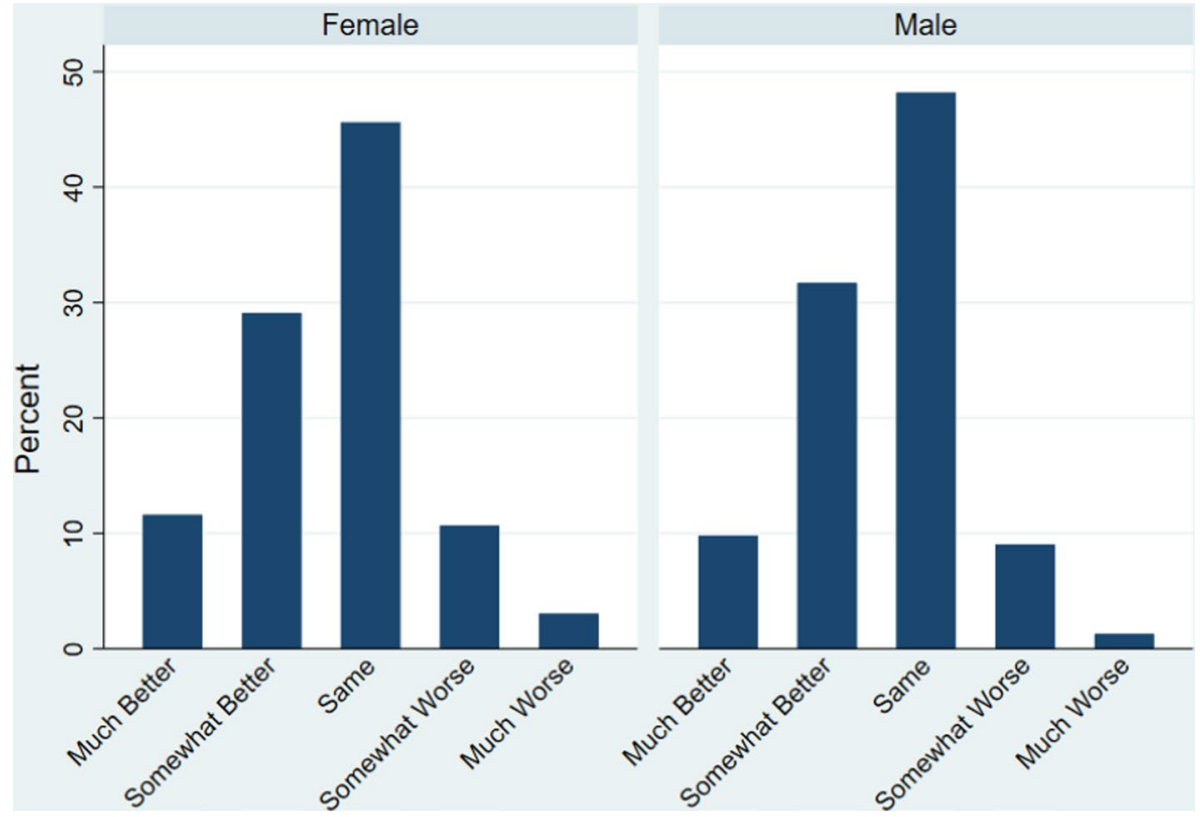

Fig. 3 Respondent's financial situation 12 months from now

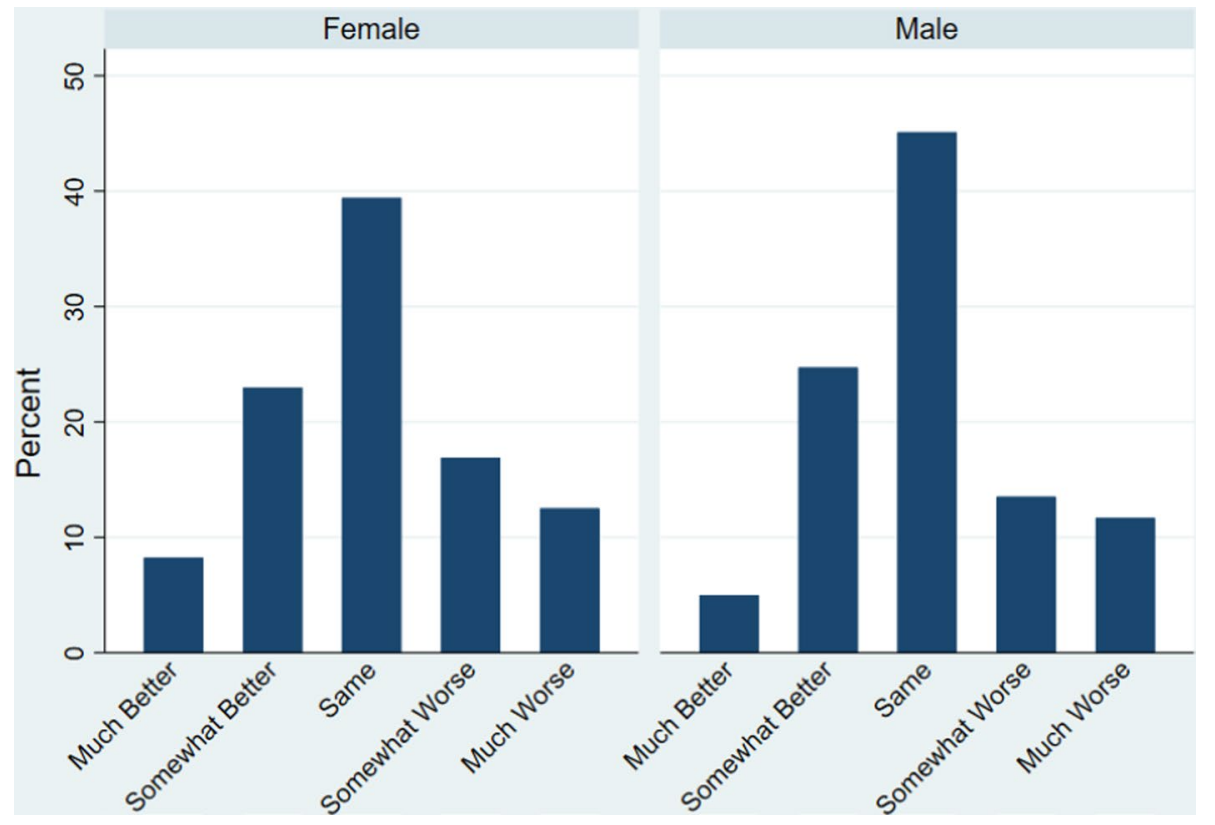

Fig. 4 National economy better or worse in last year 


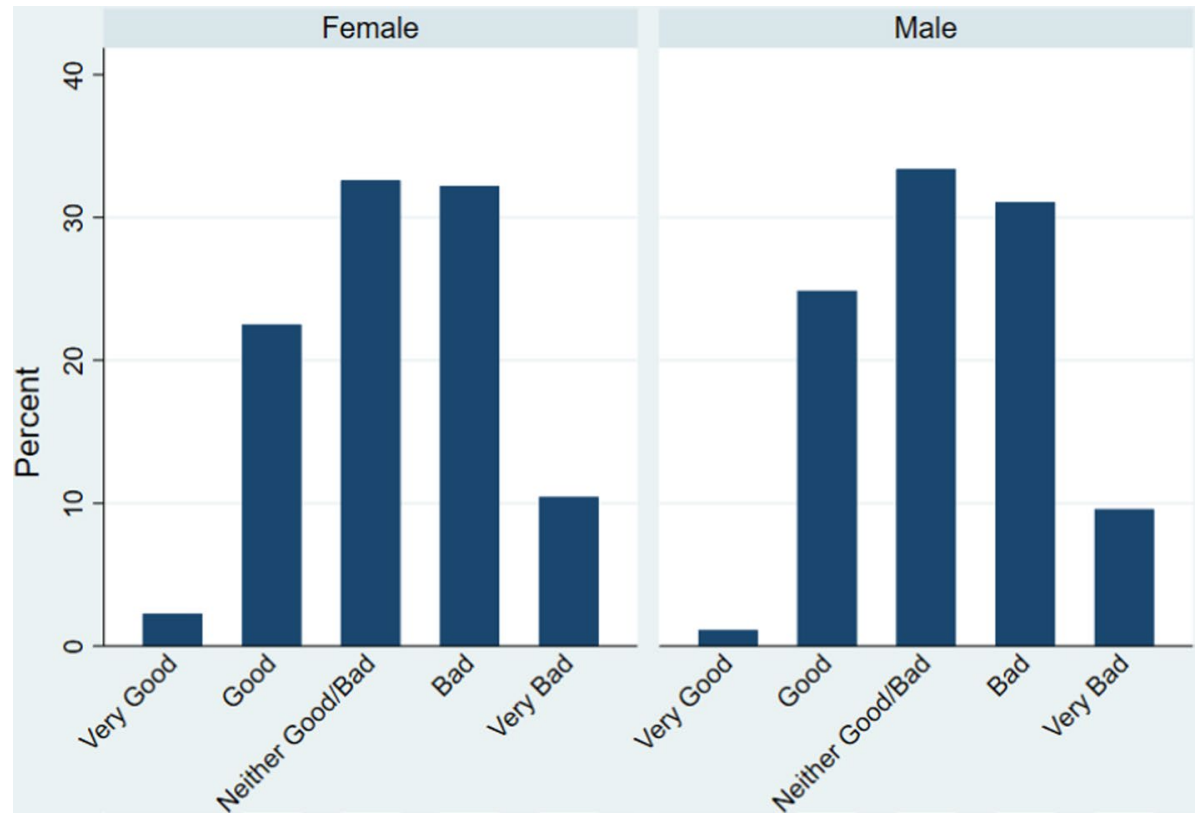

Fig. 5 Current economy good or bad

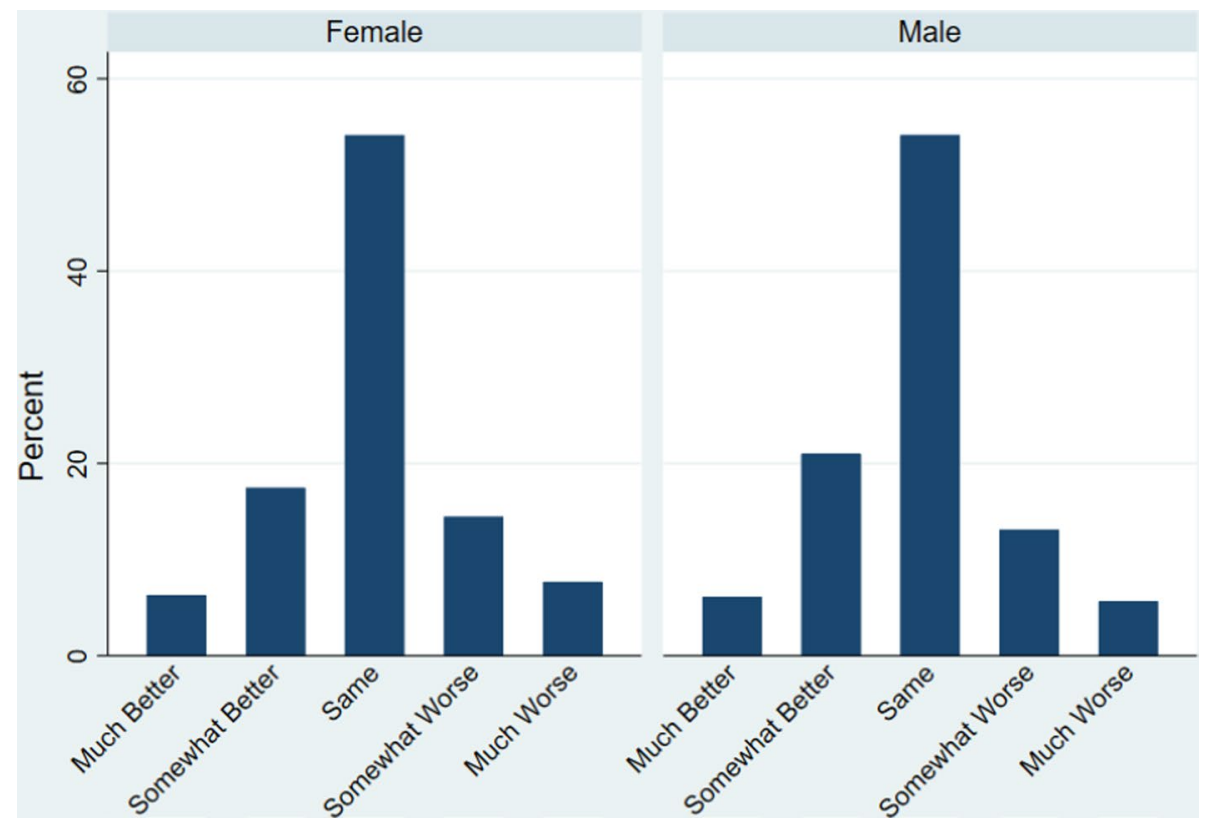

Fig. 6 Economy better or worse in next 12 months 
variable is comprised of five categorical options, small cell sizes in some response categories forced us to recode the data to binary form ${ }^{21}$ implying the following regression model, consisting of three separate dummy variables for predictors of microeconomic insecurity (Micro) along with predictors macroeconomic insecurity (Macro):

$$
y_{i}=\alpha_{0}+\sum_{j=1}^{3} \beta_{j} \text { Micro }_{j, i}+\sum_{k=4}^{6} \beta_{k} \text { Macro }_{k, i}+P_{i}^{\prime} \gamma+S_{i}^{\prime} \delta+\text { Gov }_{i}^{\prime} \epsilon+v_{i} .
$$

A dummy variable approach can also be considered as a non-linear test of the continuous linear relationship between insecurity and our dependent variables - i.e. asking the question: are key findings robust to a change in functional form?

Results are presented in "Appendix" Tables 15 and 16 for males and females respectively and are generally consistent with our results using principal component analysis. However, decomposition does indicate that our previous finding, that our predictor of micro-level insecurity influences distrust in government, seems to be driven by men who believe their financial position has worsened and by women who believe their position will worsen. In each case, such individuals are about 5-6 percentage points more likely to "never" trust the government. Moreover, females whose household financial circumstances worsened tend to have more negative views regarding the Black Lives Matter movement, Feminists, and Muslims (associations ranged from about 5-7 points in terms of magnitude) and are more supportive of Trump and less so of Clinton, by about 7-8 points in both cases.

Decomposing our predictor of macro-level insecurity into its past, present and future dimensions (i.e., whether the economy has gotten better or worse in the last year, is good or bad or will get better or worse in the next year) reinforces the salience of both current and backward-looking perceptions. Both male and female results seem to be driven by perceptions of a past worsening economic state and an overall poor current economy. Increased support for Trump among men who viewed the economy as having worsened is notably large - about 18 points, almost double what is expected given a one standard deviation increase in our derived index. But regardless of functional form, it would appear that while microeconomic insecurity is usually not significant, macroeconomic insecurity is - a finding primarily driven by past and present evaluations of the economy.

\subsection{Decomposition 2: The Impact of Chronic Insecurity}

As discussed in Watson and Osberg (2017), economic insecurity may be a chronic state or a one-time event. They further argue that repeated bouts of economic insecurity accumulate in their impacts and eventually have a "breaking" effect on an individual's mental health, which has been found to be predictor of negative flow-on effects including obesity

\footnotetext{
21 Concerning the respondent's financial position relative to both the year prior and upcoming year, responses of "somewhat worse off" and "much worse off" are coded as one; zero if they responded "much better off", "somewhat better off", or "about the same". Job insecurity equals one if the respondent was "moderately", "very" or "extremely" worried about losing their job (or finding one if jobless); zero if they were "not at all" or "a little" worried. In terms of macroeconomic performance over the past year, a value of one is given if the respondent believed the economy had gotten "somewhat worse" or "much worse"; zero if it had gotten "much better", "somewhat better" or has stayed "about the same". Responses and coding are the same in the case of future macroeconomic perception, and in terms of the current economy, we derive a dummy variable equal to one if the respondent viewed it as "bad" or "very bad"; zero if "very good", "good" or "neither good nor bad".
} 
(Dallman et al. 2003), heart disease (Stansfeld et al. 2002) and even suicide (Stravynski and Boyer 2001). This section asks whether "chronic insecurity" - in the sense of respondents believing their financial position has worsened over 12 months and will continue to deteriorate - also manifests in more support for authoritarianism, poorer views of "outgroups", and more support for Donald Trump.

Relative to the reference category of the respondent's financial situation having improved and continuing to improve, three dummy variables distinguish the respondent's situation: (i) having worsened, (ii) worsening, and (iii) both having worsened and worsening. In terms of macro-level insecurity, the same approach is taken relative to views on the economy. Like Equation 6, this robustness check also tests for a non-linear relationship between insecurity and our outcome variables.

"Appendix" Tables 17 and 18 present results for men and women respectively, which echo those of the previous sections. Chronic micro insecurity is associated with a 10 and 15 percentage point increase in the likelihood of never trusting the government for women and men respectively and has a negative impact on male support for Clinton that is almost 9 points lower than those who have not experienced any micro insecurity. Chronically micro insecure females have a level of support for Trump that is predicted to be almost 10 points higher. However, the impacts of micro-level insecurity continue to be smaller and less often statistically significant than those of macroeconomic insecurity.

Macroeconomic results for both males and females are driven by both those who viewed the economy as worsening over the prior 12 months, and those who believed that not only has the economy worsened, but would continue to do so over the upcoming year. Magnitudes are roughly comparable, although chronic level insecurity results tend to be slightly smaller, but in the case of support for Trump, almost twice as large (24 vs. 13 for men and 18 vs 8 for women). Confirming our original findings, we again conclude that micro-level insecurity has little impact on political attitudes; while macroeconomic insecurity matters (especially in terms of retrospective evaluation), regardless of functional form.

\section{Discussion}

Political behaviour is driven by much more than economics, but the economy does matter. Within the set of economic variables, our results suggest that it is primarily macro-level perceptions of economic outcomes which influence political attitudes. ${ }^{22}$ Specifically, higher levels of macroeconomic insecurity are associated with more adverse feelings toward outsiders, more authoritarianism and, in the 2016 US presidential election, higher levels of support for Donald Trump and reduced preference for Hillary Clinton. These results are not merely a reflection of political identity and are robust to the inclusion of more objective predictors of macroeconomic conditions and to decompositions of functional form. However, microeconomic insecurity does not have the same impact on political attitudes as perceptions of macroeconomic insecurity.

\footnotetext{
${ }^{22}$ We also developed an index of "tolerance", based on the respondent's collective views regarding socalled outsiders (results available upon request). Derived in the same fashion as our insecurity indices (i.e., using principal component analysis and standardized to have a mean of 0 and standard deviation of 1), a one standard deviation increase in tolerance was associated with less support for Trump and more positive feelings toward Clinton. While our macro-level insecurity variable remained statistically significant, its impact was about half the size of the tolerance variable.
} 
Our results are, in an important sense, optimistic. Public policy can affect "macro" insecurity - e.g., by shifts in monetary and fiscal policy to stimulate aggregate demand and employment. If authoritarian, xenophobic, racist, homophobic, anti-Semitic and Islamophobic attitudes are influenced by macro insecurity and are not just innate "deplorable" personal characteristics, public policy which influences macro insecurity can thereby influence these attitudes, and the political choices they imply.

We note that the rhetoric of conservative politicians seems to have shifted over time towards more sociotropic emphasis. In 1980, Ronald Reagan asked: "Are you better off than you were four years ago?" - a very direct appeal to individual well-being. ${ }^{23}$ In 1987, Margaret Thatcher notoriously declared that: "There is no such thing as society" (Keay 1987). Reagan and Thatcher were politicians of the 1980s. But the decades since have seen widespread factory closures and stagnant or declining real wages for working class Americans. ${ }^{24}$ Donald Trump's 2016 pledge to "Make America Great Again" was very different in focus - sociotropic, in fact. Has conservative rhetoric shifted its focus partly because of these macro trends?

The data of this paper is drawn from 2016, so we have no direct evidence on the causes of long term trends. We can only conjecture that the "imagined community" of nationalism $^{25}$ may have come to seem more important for people who are relatively poor, because they do not have the security that comes with wealth and because poor Americans have relatively little state social protection from economic hazards. When they have little or no social safety net, individuals have to depend more on informal support from a specific community of "similar" individuals when times turn bad, which may make them particularly sensitive to a perceived erosion of that imagined community and particularly responsive to a "strong man" who promises to defend it.

In a recent paper, Baccini and Weymouth (2021) found that white voters were more likely to support Trump in light of local manufacturing layoffs, with their argument being this group perceives such job losses as a threat to upward mobility. Replication of their method using ANES data suggests that their measure of job displacement is far more correlated with our macro insecurity index than with our micro metric. Hence, it would seem this finding corroborates our results in that local economic conditions are associated with macroeconomic concerns, ultimately leading to increased endorsement of the 2016 Republican candidate.

Our results indicate that in 2016, greater "macro" insecurity among Americans of working age fostered a rising interest in authoritarianism and distrust of government. Additionally it is also associated with more negative attitudes on race, gender, those of Jewish or Islamic faith, immigration and Hillary Clinton - and more support for Donald Trump. However, unpacking the reasons why sociotropic concerns underpin authoritarian impulses and why the balance between sociotropic and egotropic motivators of political behavior may have shifted over time remain important areas for further research.

\section{Appendix}

See Tables 6, 7, 8, 9, 10, 11, 12, 13, 14, 15, 16, 17, 18.

See Fig. 7.

\footnotetext{
${ }^{23}$ Kamarch (2012) notes that this question, posed by Reagan during their only national debate, occurred just before then incumbent, Jimmy Carter, experienced a dramatic decline in support, ultimately losing the election and popular vote.

24 Between 1979 and 2019 the median real wage of US workers with less than High School declined by 14.2 percent - See: Congressional Research Service (2020).

25 See: Anderson (1983).
} 
Table 6 Pairwise correlations of outcome variables with support for Trump and Clinton

\begin{tabular}{|c|c|c|c|c|}
\hline & \multicolumn{2}{|l|}{ Males } & \multicolumn{2}{|l|}{ Females } \\
\hline & Trump & Clinton & Trump & Clinton \\
\hline Distrust & 0.186 & -0.322 & 0.209 & -0.333 \\
\hline Authoritarianism & 0.337 & -0.163 & 0.246 & -0.154 \\
\hline \multicolumn{5}{|l|}{ Xenophobia } \\
\hline Immigration level should be decreased & 0.490 & -0.373 & 0.464 & -0.407 \\
\hline Immigration harms American culture & 0.423 & -0.288 & 0.430 & -0.335 \\
\hline Immigration is bad for the economy & 0.414 & -0.340 & 0.348 & -0.347 \\
\hline \multicolumn{5}{|l|}{ Racism } \\
\hline Blacks & -0.245 & 0.270 & -0.284 & 0.267 \\
\hline Hispanics & -0.280 & 0.257 & -0.249 & 0.204 \\
\hline Black lives matter & -0.495 & 0.612 & -0.550 & 0.581 \\
\hline \multicolumn{5}{|l|}{ Homophobia and female empowerment } \\
\hline Gays and lesbians & -0.353 & 0.308 & -0.361 & 0.321 \\
\hline Transgenders & -0.397 & 0.367 & -0.385 & 0.368 \\
\hline Feminists & -0.376 & 0.466 & -0.444 & 0.457 \\
\hline \multicolumn{5}{|l|}{ Religion } \\
\hline Jews & -0.111 & 0.146 & -0.082 & 0.084 \\
\hline Muslims & -0.466 & 0.443 & -0.403 & 0.409 \\
\hline
\end{tabular}

Dataset: 2016 American National Election Studies. Correlations are based on 1020 male observations and 1003 female observations. All pairwise correlation coefficients are statistically significant at the 1 percent level. Distrust is measured on a 5-point scale ranging from a belief that Washington will "always" do what is right [1] to "never [5]. Authoritarianism is captured using an 8-point index, increasing in authoritative support. Xenophobia variables are all on a 5-point scale, increasing in negative views concerning immigrants. The remaining variables are all measured on a 100-point scale-known as feeling thermometers, each is increasing in support for that particular variable

Table 7 Principal component analysis results

\begin{tabular}{lllll}
\hline Micro-level insecurity & & & Macro-level insecurity & \\
\cline { 5 - 5 } & Eigenvalue & & Component 1 & Eigenvalue \\
\hline Component 1 & 1.518 & & Component 2 & 1.768 \\
Component 2 & 0.895 & & Component 3 & 0.814 \\
Component 3 & 0.588 & & & 0.418 \\
& Correlation with & & Variable & Correlation with \\
Variable & Component 1 & & Economy will worsen & 0.442 \\
Financial state will worsen & 0.602 & & Economy has worsened & 0.637 \\
Financial state worsened & 0.662 & & Current economy is poor & 0.632 \\
Is currently job insecure & 0.447 & & &
\end{tabular}

Dataset: 2016 American National Election Studies. Each variable is reported on a 5-point scale, increasing in agreement with the statement. However, prior to running this analysis, each variable was standardized to have a mean of 0 and standard deviation of 1 
Table 8 Distrust regression results

\begin{tabular}{|c|c|c|}
\hline & Males & Females \\
\hline \multirow[t]{2}{*}{ Micro insecurity index } & $0.015^{*}$ & $0.015^{*}$ \\
\hline & $(0.008)$ & $(0.008)$ \\
\hline \multirow[t]{2}{*}{ Macro insecurity index } & $0.054^{* * *}$ & $0.048^{* * *}$ \\
\hline & $(0.011)$ & $(0.009)$ \\
\hline \multirow[t]{2}{*}{ Is a republican } & -0.001 & $0.065^{* * *}$ \\
\hline & $(0.020)$ & $(0.021)$ \\
\hline \multirow[t]{2}{*}{ Is an independent } & 0.014 & 0.018 \\
\hline & $(0.018)$ & $(0.014)$ \\
\hline \multirow[t]{2}{*}{$\ln$ (income) } & 0.004 & 0.011 \\
\hline & $(0.009)$ & $(0.007)$ \\
\hline \multirow[t]{2}{*}{ Educ: HS or less } & -0.007 & -0.004 \\
\hline & $(0.014)$ & $(0.013)$ \\
\hline \multirow[t]{2}{*}{ Is a born-again christian } & -0.009 & 0.004 \\
\hline & $(0.017)$ & $(0.016)$ \\
\hline \multirow[t]{2}{*}{ Age } & 0.000 & 0.000 \\
\hline & $(0.001)$ & $(0.001)$ \\
\hline \multirow[t]{2}{*}{ Is a visible minority } & $-0.048^{* * *}$ & 0.005 \\
\hline & $(0.018)$ & $(0.016)$ \\
\hline \multirow[t]{2}{*}{ Is an immigrant } & $-0.058^{* * *}$ & $-0.040^{* *}$ \\
\hline & $(0.020)$ & $(0.018)$ \\
\hline \multirow[t]{2}{*}{ Is divorced } & 0.005 & $0.036^{*}$ \\
\hline & $(0.023)$ & $(0.022)$ \\
\hline \multirow[t]{2}{*}{ Is widowed } & -0.022 & -0.022 \\
\hline & $(0.038)$ & $(0.035)$ \\
\hline \multirow[t]{2}{*}{ Is single } & 0.014 & -0.001 \\
\hline & $(0.020)$ & $(0.017)$ \\
\hline \multirow[t]{2}{*}{ Governor is a democrat } & 0.000 & -0.002 \\
\hline & $(0.016)$ & $(0.014)$ \\
\hline Observations & 1020 & 1003 \\
\hline
\end{tabular}

$* * * p<0.01, * * p<0.05, * p<0.1$. Standard errors are in parentheses. Dataset: 2016 American National Election Studies. Estimates are derived using an ordinal probit specification where average marginal effects are presented in reference to being in most distrustful category. 
Table 9 Authoritarianism regression results

\begin{tabular}{|c|c|c|}
\hline & Males & Females \\
\hline Micro insecurity index & $\begin{array}{l}-0.019 \\
(0.102)\end{array}$ & $\begin{array}{l}0.106 \\
(0.094)\end{array}$ \\
\hline Macro insecurity index & $\begin{array}{l}0.397^{* * *} \\
(0.105)\end{array}$ & $\begin{array}{l}0.342^{* * *} \\
(0.101)\end{array}$ \\
\hline Is a republican & $\begin{array}{l}0.984^{* * * *} \\
(0.228)\end{array}$ & $\begin{array}{l}0.361 \\
(0.227)\end{array}$ \\
\hline Is an independent & $\begin{array}{l}-0.032 \\
(0.213)\end{array}$ & $\begin{array}{l}-0.317 \\
(0.203)\end{array}$ \\
\hline $\ln$ (income) & $\begin{array}{l}-0.237^{* *} \\
(0.093)\end{array}$ & $\begin{array}{l}-0.336^{* * *} \\
(0.086)\end{array}$ \\
\hline Educ: HS or less & $\begin{array}{l}1.022^{* * *} \\
(0.169)\end{array}$ & $\begin{array}{l}1.117^{* * *} \\
(0.177)\end{array}$ \\
\hline Is a born-again christian & $\begin{array}{l}0.951^{* * *} \\
(0.183)\end{array}$ & $\begin{array}{l}1.060^{* * *} \\
(0.185)\end{array}$ \\
\hline Age & $\begin{array}{l}0.014^{* *} \\
(0.006)\end{array}$ & $\begin{array}{l}-0.007 \\
(0.007)\end{array}$ \\
\hline Is a visible minority & $\begin{array}{l}1.075^{* * *} \\
(0.222)\end{array}$ & $\begin{array}{l}1.043^{* * *} \\
(0.218)\end{array}$ \\
\hline Is an immigrant & $\begin{array}{l}0.470 \\
(0.307)\end{array}$ & $\begin{array}{l}-0.416 \\
(0.278)\end{array}$ \\
\hline Is divorced & $\begin{array}{l}-0.138 \\
(0.266)\end{array}$ & $\begin{array}{l}-0.036 \\
(0.212)\end{array}$ \\
\hline Is widowed & $\begin{array}{l}0.504 \\
(0.475)\end{array}$ & $\begin{array}{l}0.283 \\
(0.555)\end{array}$ \\
\hline Is single & $\begin{array}{l}-0.476^{* *} \\
(0.215)\end{array}$ & $\begin{array}{l}-0.535^{* *} \\
(0.233)\end{array}$ \\
\hline Democrat governor & $\begin{array}{l}-0.304^{*} \\
(0.178)\end{array}$ & $\begin{array}{c}-0.203 \\
(0.180)\end{array}$ \\
\hline Constant & $\begin{array}{l}5.142^{* * *} \\
(1.127)\end{array}$ & $\begin{array}{l}7.279^{* * *} \\
(1.028)\end{array}$ \\
\hline Observations & 1020 & 1003 \\
\hline
\end{tabular}

$* * * p<0.01, * * p<0.05, * p<0.1$. Standard errors are in parentheses. Dataset: 2016 American National Election Studies. Estimates are derived using OLS. 
Table 10 Regression results-Xenophobia

\begin{tabular}{|c|c|c|c|c|c|c|}
\hline & \multicolumn{3}{|l|}{ Males } & \multicolumn{3}{|l|}{ Females } \\
\hline & Decreased & Harmful & Bad econ & Decreased & Harmful & Bad econ \\
\hline \multirow[t]{2}{*}{ Micro insecurity index } & -0.006 & 0.002 & -0.000 & -0.003 & -0.001 & 0.001 \\
\hline & $(0.012)$ & $(0.005)$ & $(0.005)$ & $(0.011)$ & $(0.004)$ & $(0.005)$ \\
\hline \multirow[t]{2}{*}{ Macro insecurity index } & $0.088^{* * *}$ & $0.023^{* * *}$ & $0.035^{* * *}$ & $0.058^{* * *}$ & $0.017^{* * *}$ & $0.030^{* * *}$ \\
\hline & $(0.015)$ & $(0.006)$ & $(0.007)$ & $(0.013)$ & $(0.005)$ & $(0.006)$ \\
\hline \multirow[t]{2}{*}{ Is a republican } & $0.153^{* * *}$ & $0.049^{* * *}$ & $0.058^{* * *}$ & $0.150^{* * *}$ & $0.045^{* * *}$ & $0.038^{* * *}$ \\
\hline & $(0.037)$ & $(0.013)$ & $(0.014)$ & $(0.035)$ & $(0.013)$ & $(0.013)$ \\
\hline \multirow[t]{2}{*}{ Is an independent } & 0.025 & -0.000 & 0.011 & $0.038^{*}$ & 0.009 & 0.013 \\
\hline & $(0.025)$ & $(0.008)$ & (0.009) & $(0.022)$ & $(0.007)$ & $(0.009)$ \\
\hline \multirow[t]{2}{*}{$\ln$ (income) } & -0.005 & $-0.010^{* *}$ & $-0.017^{* * *}$ & $-0.017^{*}$ & $-0.013^{* * *}$ & $-0.010^{* *}$ \\
\hline & $(0.014)$ & $(0.005)$ & $(0.005)$ & $(0.010)$ & $(0.004)$ & $(0.005)$ \\
\hline \multirow[t]{2}{*}{ Educ: HS or less } & $0.057^{* *}$ & $0.038^{* * *}$ & $0.037^{* * *}$ & $0.063^{* * *}$ & $0.036^{* * *}$ & $0.033^{* * *}$ \\
\hline & $(0.024)$ & $(0.009)$ & $(0.010)$ & $(0.021)$ & $(0.009)$ & $(0.010)$ \\
\hline \multirow[t]{2}{*}{ Is a born-again christian } & 0.022 & $0.027^{* * *}$ & -0.004 & 0.005 & 0.013 & 0.010 \\
\hline & $(0.028)$ & $(0.010)$ & $(0.010)$ & $(0.020)$ & $(0.008)$ & $(0.009)$ \\
\hline \multirow[t]{2}{*}{ Age } & $0.002^{* *}$ & -0.000 & -0.000 & $0.003^{* * *}$ & 0.000 & 0.000 \\
\hline & $(0.001)$ & $(0.000)$ & $(0.000)$ & $(0.001)$ & $(0.000)$ & $(0.000)$ \\
\hline \multirow[t]{2}{*}{ Is a visible minority } & -0.025 & 0.003 & -0.006 & -0.009 & 0.001 & 0.001 \\
\hline & $(0.027)$ & $(0.010)$ & $(0.011)$ & $(0.025)$ & $(0.010)$ & $(0.012)$ \\
\hline \multirow[t]{2}{*}{ Is an immigrant } & $-0.062^{*}$ & $-0.022^{*}$ & $-0.049^{* * *}$ & $-0.065^{* *}$ & -0.015 & $-0.041^{\text {**** }}$ \\
\hline & $(0.034)$ & $(0.012)$ & $(0.009)$ & $(0.033)$ & $(0.009)$ & $(0.009)$ \\
\hline \multirow[t]{2}{*}{ Is divorced } & -0.008 & 0.019 & 0.002 & -0.012 & -0.006 & 0.000 \\
\hline & $(0.036)$ & $(0.016)$ & $(0.016)$ & $(0.026)$ & $(0.009)$ & $(0.012)$ \\
\hline \multirow[t]{2}{*}{ Is widowed } & 0.061 & 0.042 & 0.040 & -0.052 & -0.022 & -0.020 \\
\hline & $(0.106)$ & $(0.047)$ & $(0.043)$ & $(0.038)$ & $(0.016)$ & $(0.025)$ \\
\hline \multirow[t]{2}{*}{ Is single } & -0.044 & -0.004 & -0.013 & -0.029 & -0.006 & -0.017 \\
\hline & $(0.030)$ & $(0.010)$ & $(0.011)$ & $(0.025)$ & $(0.010)$ & $(0.011)$ \\
\hline \multirow[t]{2}{*}{ Governor is a democrat } & $-0.038^{*}$ & -0.012 & $-0.016^{*}$ & -0.026 & -0.006 & -0.012 \\
\hline & $(0.023)$ & $(0.008)$ & $(0.009)$ & $(0.020)$ & $(0.007)$ & $(0.008)$ \\
\hline Observations & 1020 & 1020 & 1020 & 1003 & 1003 & 1003 \\
\hline
\end{tabular}

$* * * p<0.01, * * p<0.05, * p<0.1$. Standard errors are in parentheses. Dataset: 2016 American National Election Studies. Estimates are derived using an ordinal probit specification where average marginal effects are presented in reference to being in most xenophobic category 
Table 11 Regression results—racism

\begin{tabular}{|c|c|c|c|c|c|c|}
\hline & \multicolumn{3}{|l|}{ Males } & \multicolumn{3}{|l|}{ Females } \\
\hline & Blacks & Hispanics & B.L.M. & Blacks & Hispanics & B.L.M. \\
\hline Micro insecurity index & $\begin{array}{l}0.165 \\
(0.961)\end{array}$ & $\begin{array}{l}0.048 \\
(0.978)\end{array}$ & $\begin{array}{l}-1.628 \\
(1.468)\end{array}$ & $\begin{array}{l}0.523 \\
(0.877)\end{array}$ & $\begin{array}{l}-0.571 \\
(0.924)\end{array}$ & $\begin{array}{l}-0.303 \\
(1.136)\end{array}$ \\
\hline Macro insecurity index & $\begin{array}{l}-3.543^{* * *} \\
(1.050)\end{array}$ & $\begin{array}{l}-3.389^{* * *} \\
(1.019)\end{array}$ & $\begin{array}{l}-8.109^{* * *} \\
(1.350)\end{array}$ & $\begin{array}{l}-2.452^{* *} \\
(0.967)\end{array}$ & $\begin{array}{l}-3.173^{* * *} \\
(0.969)\end{array}$ & $\begin{array}{l}-4.910^{* * *} \\
(1.137)\end{array}$ \\
\hline Is a republican & $\begin{array}{l}-8.584^{* * *} \\
(2.433)\end{array}$ & $\begin{array}{l}-7.325^{* * *} \\
(2.194)\end{array}$ & $\begin{array}{l}-23.274^{* * *} \\
(3.095)\end{array}$ & $\begin{array}{l}-7.853^{* * *} \\
(2.247)\end{array}$ & $\begin{array}{l}-3.866^{*} \\
(2.347)\end{array}$ & $\begin{array}{l}-30.589^{\text {**** }} \\
(3.053)\end{array}$ \\
\hline Is an independent & $\begin{array}{l}-5.657^{* *} \\
(2.299)\end{array}$ & $\begin{array}{l}-4.884^{* *} \\
(2.012)\end{array}$ & $\begin{array}{l}-14.261^{* * *} \\
(2.906)\end{array}$ & $\begin{array}{l}-6.311^{* * *} \\
(1.752)\end{array}$ & $\begin{array}{l}-1.046 \\
(1.888)\end{array}$ & $\begin{array}{l}-11.742^{\text {**** }} \\
(2.280)\end{array}$ \\
\hline $\ln$ (income) & $\begin{array}{l}1.759^{*} \\
(1.021)\end{array}$ & $\begin{array}{l}1.373 \\
(0.982)\end{array}$ & $\begin{array}{l}-0.779 \\
(1.262)\end{array}$ & $\begin{array}{l}1.062 \\
(0.829)\end{array}$ & $\begin{array}{l}2.095^{* *} \\
(0.854)\end{array}$ & $\begin{array}{l}-0.217 \\
(1.055)\end{array}$ \\
\hline Educ: HS or less & $\begin{array}{l}-1.594 \\
(1.594)\end{array}$ & $\begin{array}{l}-3.865^{* *} \\
(1.622)\end{array}$ & $\begin{array}{l}4.706^{* *} \\
(2.205)\end{array}$ & $\begin{array}{l}-3.205^{* *} \\
(1.571)\end{array}$ & $\begin{array}{l}-2.795^{*} \\
(1.652)\end{array}$ & $\begin{array}{l}-4.544^{* *} \\
(1.928)\end{array}$ \\
\hline Is a born-again christian & $\begin{array}{l}3.251^{*} \\
(1.877)\end{array}$ & $\begin{array}{l}0.023 \\
(1.787)\end{array}$ & $\begin{array}{l}-0.690 \\
(2.430)\end{array}$ & $\begin{array}{l}3.881^{* *} \\
(1.678)\end{array}$ & $\begin{array}{l}1.666 \\
(1.780)\end{array}$ & $\begin{array}{l}1.479 \\
(2.115)\end{array}$ \\
\hline Age & $\begin{array}{l}0.028 \\
(0.062)\end{array}$ & $\begin{array}{l}0.020 \\
(0.066)\end{array}$ & $\begin{array}{l}0.090 \\
(0.081)\end{array}$ & $\begin{array}{l}0.046 \\
(0.060)\end{array}$ & $\begin{array}{l}-0.025 \\
(0.063)\end{array}$ & $\begin{array}{l}0.009 \\
(0.081)\end{array}$ \\
\hline Is a visible minority & $\begin{array}{l}3.847^{*} \\
(2.060)\end{array}$ & $\begin{array}{l}3.353^{*} \\
(1.968)\end{array}$ & $\begin{array}{l}14.460^{* * *} \\
(2.848)\end{array}$ & $\begin{array}{l}4.761^{* *} \\
(1.883)\end{array}$ & $\begin{array}{l}2.022 \\
(2.043)\end{array}$ & $\begin{array}{l}13.356^{* * *} \\
(2.440)\end{array}$ \\
\hline Is an immigrant & $\begin{array}{l}-6.330^{* *} \\
(2.905)\end{array}$ & $\begin{array}{l}0.854 \\
(2.867)\end{array}$ & $\begin{array}{l}2.442 \\
(4.039)\end{array}$ & $\begin{array}{l}-5.206 \\
(3.199)\end{array}$ & $\begin{array}{l}2.515 \\
(3.050)\end{array}$ & $\begin{array}{l}-5.396 \\
(4.636)\end{array}$ \\
\hline Is divorced & $\begin{array}{l}-5.850^{* *} \\
(2.427)\end{array}$ & $\begin{array}{l}-5.798^{* * *} \\
(2.237)\end{array}$ & $\begin{array}{l}-3.048 \\
(3.010)\end{array}$ & $\begin{array}{l}4.068^{* *} \\
(1.974)\end{array}$ & $\begin{array}{l}1.511 \\
(2.152)\end{array}$ & $\begin{array}{l}2.919 \\
(2.620)\end{array}$ \\
\hline Is widowed & $\begin{array}{l}-7.123 \\
(8.732)\end{array}$ & $\begin{array}{l}-8.561 \\
(9.081)\end{array}$ & $\begin{array}{l}-5.133 \\
(10.485)\end{array}$ & $\begin{array}{l}4.464 \\
(4.300)\end{array}$ & $\begin{array}{l}9.176^{* *} \\
(4.524)\end{array}$ & $\begin{array}{l}-9.308^{*} \\
(5.196)\end{array}$ \\
\hline Is single & $\begin{array}{l}0.066 \\
(2.061)\end{array}$ & $\begin{array}{l}-1.688 \\
(2.106)\end{array}$ & $\begin{array}{l}3.809 \\
(2.854)\end{array}$ & $\begin{array}{l}8.790^{* * * *} \\
(2.066)\end{array}$ & $\begin{array}{l}6.997^{* * * *} \\
(2.162)\end{array}$ & $\begin{array}{l}12.993^{* * *} \\
(2.709)\end{array}$ \\
\hline Democrat governor & $\begin{array}{l}1.428 \\
(1.635)\end{array}$ & $\begin{array}{l}1.656 \\
(1.640)\end{array}$ & $\begin{array}{l}1.527 \\
(2.215)\end{array}$ & $\begin{array}{l}-1.367 \\
(1.615)\end{array}$ & $\begin{array}{l}-2.182 \\
(1.647)\end{array}$ & $\begin{array}{l}-0.222 \\
(1.995)\end{array}$ \\
\hline Constant & $\begin{array}{l}50.336^{* * *} \\
(12.209)\end{array}$ & $\begin{array}{l}56.618^{* * *} \\
(11.114)\end{array}$ & $\begin{array}{l}53.904^{* * *} \\
(14.967)\end{array}$ & $\begin{array}{l}57.970^{* * *} \\
(10.003)\end{array}$ & $\begin{array}{l}48.087^{* * *} \\
(10.161)\end{array}$ & $\begin{array}{l}62.353^{* * *} \\
(12.807)\end{array}$ \\
\hline Observations & 1020 & 1020 & 1020 & 1003 & 1003 & 1003 \\
\hline
\end{tabular}

$* * * p<0.01, * * p<0.05, * p<0.1$. Standard errors are in parentheses. Dataset: 2016 American National Election Studies. Estimates are derived using OLS 
Table 12 Regression results-homophobia

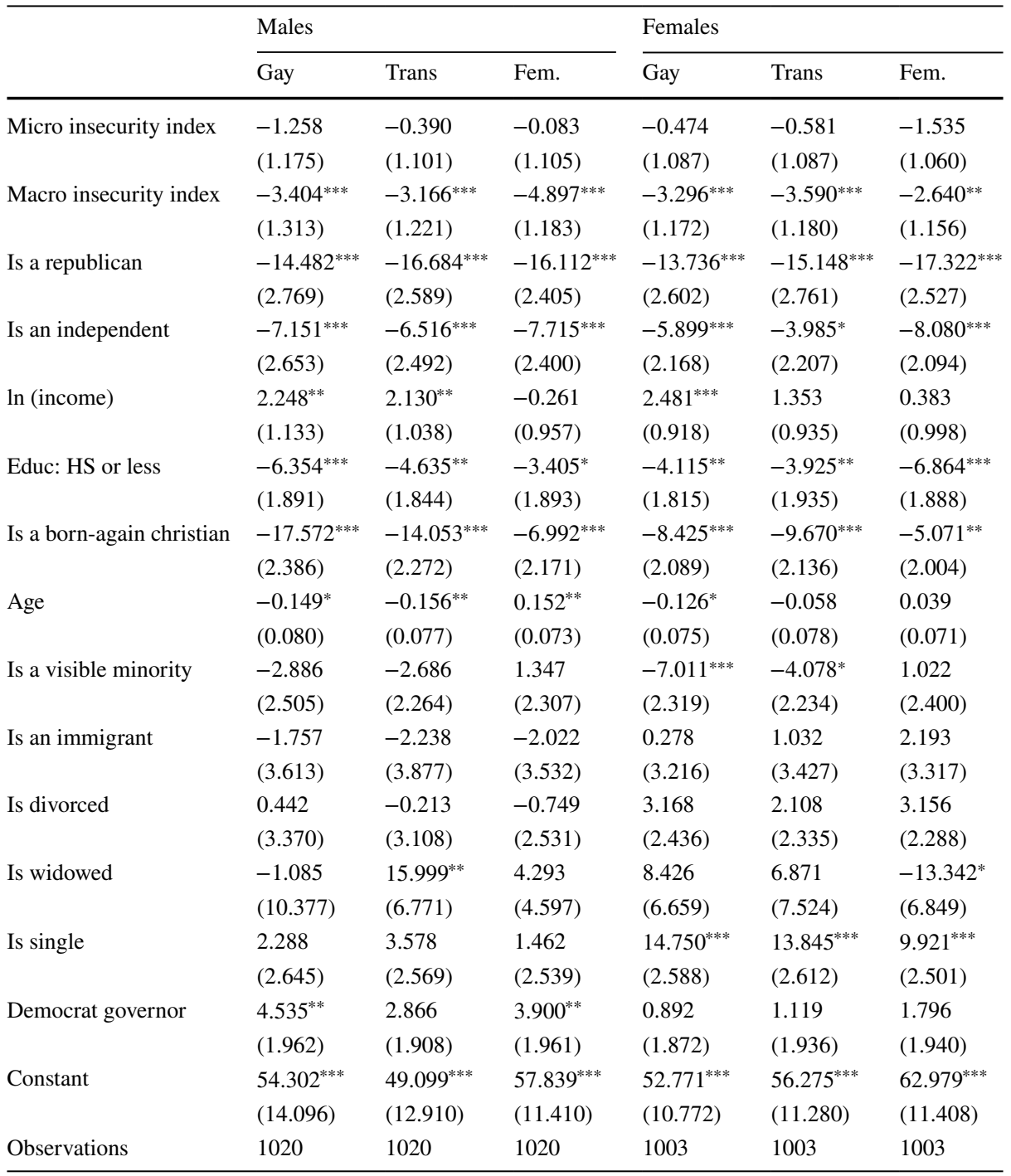

$* * * p<0.01, * * p<0.05, * p<0.1$. Standard errors are in parentheses. Dataset: 2016 American National Election Studies. Estimates are derived using OLS 
Table 13 Regression results-religion

\begin{tabular}{|c|c|c|c|c|}
\hline & \multicolumn{2}{|l|}{ Males } & \multicolumn{2}{|l|}{ Females } \\
\hline & Jews & Muslims & Jews & Muslims \\
\hline Micro insecurity index & $\begin{array}{l}0.845 \\
(1.040)\end{array}$ & $\begin{array}{l}0.085 \\
(1.175)\end{array}$ & $\begin{array}{l}-1.429 \\
(0.964)\end{array}$ & $\begin{array}{l}-1.790^{*} \\
(1.007)\end{array}$ \\
\hline Macro insecurity index & $\begin{array}{l}-2.525^{* *} \\
(1.010)\end{array}$ & $\begin{array}{l}-5.970^{* * *} \\
(1.161)\end{array}$ & $\begin{array}{l}-1.221 \\
(1.048)\end{array}$ & $\begin{array}{l}-5.497^{* * *} \\
(1.197)\end{array}$ \\
\hline Is a republican & $\begin{array}{l}-5.059^{* *} \\
(2.214)\end{array}$ & $\begin{array}{l}-16.758^{\text {**** }} \\
(2.723)\end{array}$ & $\begin{array}{l}-0.910 \\
(2.389)\end{array}$ & $\begin{array}{l}-12.516^{* * *} \\
(2.811)\end{array}$ \\
\hline Is an independent & $\begin{array}{l}-5.339^{* *} \\
(2.136)\end{array}$ & $\begin{array}{l}-5.826^{* *} \\
(2.552)\end{array}$ & $\begin{array}{l}-2.579 \\
(1.979)\end{array}$ & $\begin{array}{l}-4.568^{* *} \\
(2.189)\end{array}$ \\
\hline $\ln$ (income) & $\begin{array}{l}3.704^{* * *} \\
(0.953)\end{array}$ & $\begin{array}{l}2.369^{* *} \\
(1.088)\end{array}$ & $\begin{array}{l}2.273^{* *} \\
(0.913)\end{array}$ & $\begin{array}{l}1.221 \\
(0.954)\end{array}$ \\
\hline Educ: HS or less & $\begin{array}{l}-1.875 \\
(1.728)\end{array}$ & $\begin{array}{l}-4.013^{* *} \\
(1.897)\end{array}$ & $\begin{array}{l}-3.051^{*} \\
(1.736)\end{array}$ & $\begin{array}{l}-2.777 \\
(1.938)\end{array}$ \\
\hline Is a born-again christian & $\begin{array}{l}5.459^{* * *} \\
(1.985)\end{array}$ & $\begin{array}{l}-2.628 \\
(2.377)\end{array}$ & $\begin{array}{l}1.952 \\
(1.942)\end{array}$ & $\begin{array}{l}-2.034 \\
(2.088)\end{array}$ \\
\hline Age & $\begin{array}{l}0.100 \\
(0.070)\end{array}$ & $\begin{array}{l}-0.098 \\
(0.078)\end{array}$ & $\begin{array}{l}0.100 \\
(0.067)\end{array}$ & $\begin{array}{l}0.018 \\
(0.073)\end{array}$ \\
\hline Is a visible minority & $\begin{array}{l}-2.614 \\
(2.088)\end{array}$ & $\begin{array}{l}2.405 \\
(2.440)\end{array}$ & $\begin{array}{l}-2.951 \\
(2.134)\end{array}$ & $\begin{array}{l}-1.070 \\
(2.314)\end{array}$ \\
\hline Is an immigrant & $\begin{array}{l}0.814 \\
(2.918)\end{array}$ & $\begin{array}{l}0.970 \\
(3.903)\end{array}$ & $\begin{array}{l}-3.195 \\
(3.003)\end{array}$ & $\begin{array}{l}0.460 \\
(3.460)\end{array}$ \\
\hline Is divorced & $\begin{array}{l}-2.310 \\
(2.825)\end{array}$ & $\begin{array}{l}-0.352 \\
(3.130)\end{array}$ & $\begin{array}{l}-2.615 \\
(2.363)\end{array}$ & $\begin{array}{l}2.426 \\
(2.429)\end{array}$ \\
\hline Is widowed & $\begin{array}{l}-2.201 \\
(9.353)\end{array}$ & $\begin{array}{l}-0.117 \\
(7.656)\end{array}$ & $\begin{array}{l}7.746 \\
(4.828)\end{array}$ & $\begin{array}{l}2.996 \\
(4.962)\end{array}$ \\
\hline Is single & $\begin{array}{l}1.172 \\
(2.345)\end{array}$ & $\begin{array}{l}3.148 \\
(2.447)\end{array}$ & $\begin{array}{l}4.215^{*} \\
(2.269)\end{array}$ & $\begin{array}{l}9.880^{* * *} \\
(2.548)\end{array}$ \\
\hline Democrat governor & $\begin{array}{l}1.017 \\
(1.726)\end{array}$ & $\begin{array}{l}2.369 \\
(1.983)\end{array}$ & $\begin{array}{l}-0.899 \\
(1.761)\end{array}$ & $\begin{array}{l}2.181 \\
(1.985)\end{array}$ \\
\hline Constant & $\begin{array}{l}25.598^{* *} \\
(11.428)\end{array}$ & $\begin{array}{l}38.034^{* * *} \\
(12.682)\end{array}$ & $\begin{array}{l}45.944^{* * *} \\
(10.814)\end{array}$ & $\begin{array}{l}47.985^{* * *} \\
(11.433)\end{array}$ \\
\hline Observations & 1020 & 1020 & 1003 & 1003 \\
\hline
\end{tabular}

$* * * p<0.01, * * p<0.05, * p<0.1$. Standard errors are in parentheses. Dataset: 2016 American National Election Studies. Estimates are derived using OLS 
Table 14 Regression results-political support

\begin{tabular}{|c|c|c|c|c|}
\hline & \multicolumn{2}{|l|}{ Males } & \multicolumn{2}{|l|}{ Females } \\
\hline & Clinton & Trump & Clinton & Trump \\
\hline Micro insecurity index & $\begin{array}{l}-0.736 \\
(1.104)\end{array}$ & $\begin{array}{l}-1.282 \\
(1.326)\end{array}$ & $\begin{array}{l}-0.299 \\
(1.133)\end{array}$ & $\begin{array}{l}0.064 \\
(1.262)\end{array}$ \\
\hline Macro insecurity index & $\begin{array}{l}-9.311^{* * *} \\
(1.129)\end{array}$ & $\begin{array}{l}9.605^{* * *} \\
(1.378)\end{array}$ & $\begin{array}{l}-10.884^{* * *} \\
(1.108)\end{array}$ & $\begin{array}{l}7.400^{* * *} \\
(1.490)\end{array}$ \\
\hline Is a republican & $\begin{array}{l}-38.801^{\text {*** }} \\
(2.671)\end{array}$ & $\begin{array}{l}37.957^{* * *} \\
(3.108)\end{array}$ & $\begin{array}{l}-39.491^{* * *} \\
(2.553)\end{array}$ & $\begin{array}{l}38.925^{* * *} \\
(3.005)\end{array}$ \\
\hline Is an independent & $\begin{array}{l}-24.543^{\text {*** }} \\
(2.630)\end{array}$ & $\begin{array}{l}15.906^{* * *} \\
(2.968)\end{array}$ & $\begin{array}{l}-16.889^{* * *} \\
(2.329)\end{array}$ & $\begin{array}{l}15.660^{* * * *} \\
(2.369)\end{array}$ \\
\hline ln (income) & $\begin{array}{l}-0.268 \\
(1.034)\end{array}$ & $\begin{array}{l}-1.869 \\
(1.277)\end{array}$ & $\begin{array}{l}-0.245 \\
(0.856)\end{array}$ & $\begin{array}{l}-3.169^{* * *} \\
(0.954)\end{array}$ \\
\hline Educ: HS or less & $\begin{array}{l}-1.426 \\
(1.715)\end{array}$ & $\begin{array}{l}8.274^{* * *} \\
(2.015)\end{array}$ & $\begin{array}{l}-4.673^{* *} \\
(1.832)\end{array}$ & $\begin{array}{l}9.393^{* * *} \\
(1.981)\end{array}$ \\
\hline Is a born-again christian & $\begin{array}{l}-3.850^{*} \\
(2.302)\end{array}$ & $\begin{array}{l}6.562^{* *} \\
(2.569)\end{array}$ & $\begin{array}{l}0.639 \\
(2.039)\end{array}$ & $\begin{array}{l}3.844^{*} \\
(2.098)\end{array}$ \\
\hline Age & $\begin{array}{l}0.049 \\
(0.073)\end{array}$ & $\begin{array}{l}0.143 \\
(0.093)\end{array}$ & $\begin{array}{l}0.112 \\
(0.076)\end{array}$ & $\begin{array}{l}0.244^{* * *} \\
(0.080)\end{array}$ \\
\hline Is a visible minority & $\begin{array}{l}10.260^{* * *} \\
(2.783)\end{array}$ & $\begin{array}{l}-8.160^{* * * *} \\
(2.922)\end{array}$ & $\begin{array}{l}9.435^{* * *} \\
(2.347)\end{array}$ & $\begin{array}{l}-7.621^{\text {**** }} \\
(2.526)\end{array}$ \\
\hline Is an immigrant & $\begin{array}{l}4.834 \\
(3.381)\end{array}$ & $\begin{array}{l}2.930 \\
(4.143)\end{array}$ & $\begin{array}{l}1.924 \\
(3.013)\end{array}$ & $\begin{array}{l}-6.842^{*} \\
(3.775)\end{array}$ \\
\hline Is divorced & $\begin{array}{l}-0.435 \\
(2.765)\end{array}$ & $\begin{array}{l}0.475 \\
(3.645)\end{array}$ & $\begin{array}{l}3.719 \\
(2.738)\end{array}$ & $\begin{array}{l}-9.881^{\text {**** }} \\
(2.517)\end{array}$ \\
\hline Is widowed & $\begin{array}{l}7.436 \\
(6.219)\end{array}$ & $\begin{array}{l}6.616 \\
(8.117)\end{array}$ & $\begin{array}{l}2.350 \\
(4.379)\end{array}$ & $\begin{array}{l}-13.919^{* * *} \\
(4.603)\end{array}$ \\
\hline Is single & $\begin{array}{l}1.987 \\
(2.371)\end{array}$ & $\begin{array}{l}-1.467 \\
(3.041)\end{array}$ & $\begin{array}{l}8.161^{* * *} \\
(2.483)\end{array}$ & $\begin{array}{l}-8.622^{\text {**** }} \\
(2.794)\end{array}$ \\
\hline Democrat governor & $\begin{array}{l}2.926 \\
(1.898)\end{array}$ & $\begin{array}{l}-3.277 \\
(2.280)\end{array}$ & $\begin{array}{l}-0.029 \\
(1.839)\end{array}$ & $\begin{array}{l}-2.373 \\
(2.005)\end{array}$ \\
\hline Constant & $\begin{array}{l}57.791^{* * *} \\
(12.089)\end{array}$ & $\begin{array}{l}39.091^{* *} \\
(15.201)\end{array}$ & $\begin{array}{l}58.384^{* * *} \\
(11.063)\end{array}$ & $\begin{array}{l}48.483^{* * *} \\
(12.158)\end{array}$ \\
\hline Observations & 1020 & 1020 & 1003 & 1003 \\
\hline
\end{tabular}

$* * * p<0.01, * * p<0.05, * p<0.1$. Standard errors are in parentheses. Dataset: 2016 American National Election Studies. Estimates are derived using OLS 
Table 15 Decomposition 1 (males)

\begin{tabular}{|c|c|c|c|c|c|c|}
\hline & \multicolumn{3}{|c|}{ Micro variables } & \multicolumn{3}{|c|}{ Macro variables } \\
\hline & Worsened & Job ins. & Will worsen & Worsened & Is poor & Will worsen \\
\hline Distrust & $\begin{array}{l}0.048^{* *} \\
(0.024)\end{array}$ & $\begin{array}{l}0.045 \\
(0.035)\end{array}$ & $\begin{array}{l}-0.002 \\
(0.027)\end{array}$ & $\begin{array}{l}0.003 \\
(0.021)\end{array}$ & $\begin{array}{l}0.098^{* * * *} \\
(0.020)\end{array}$ & $\begin{array}{l}0.026 \\
(0.020)\end{array}$ \\
\hline Authoritarianism & $\begin{array}{l}-0.196 \\
(0.216)\end{array}$ & $\begin{array}{l}0.006 \\
(0.306)\end{array}$ & $\begin{array}{l}0.350 \\
(0.280)\end{array}$ & $\begin{array}{l}0.774^{* * *} \\
(0.219)\end{array}$ & $\begin{array}{l}0.314 \\
(0.194)\end{array}$ & $\begin{array}{l}-0.091 \\
(0.240)\end{array}$ \\
\hline \multicolumn{7}{|c|}{ Xenophobia; Immigration } \\
\hline Decreased a lot & $\begin{array}{l}-0.011 \\
(0.030)\end{array}$ & $\begin{array}{l}-0.031 \\
(0.036)\end{array}$ & $\begin{array}{l}0.053 \\
(0.042)\end{array}$ & $\begin{array}{l}0.148^{* * *} \\
(0.040)\end{array}$ & $\begin{array}{l}0.047^{*} \\
(0.028)\end{array}$ & $\begin{array}{l}0.048 \\
(0.030)\end{array}$ \\
\hline Does cultural harm & $\begin{array}{l}-0.019^{* *} \\
(0.008)\end{array}$ & $\begin{array}{l}-0.005 \\
(0.013)\end{array}$ & $\begin{array}{l}0.035^{* *} \\
(0.017)\end{array}$ & $\begin{array}{l}0.045^{* * *} \\
(0.013)\end{array}$ & $\begin{array}{l}0.022^{* *} \\
(0.009)\end{array}$ & $\begin{array}{l}-0.005 \\
(0.010)\end{array}$ \\
\hline Is bad for econ. & $\begin{array}{l}-0.011 \\
(0.011)\end{array}$ & $\begin{array}{l}-0.006 \\
(0.015)\end{array}$ & $\begin{array}{l}0.010 \\
(0.017)\end{array}$ & $\begin{array}{l}0.036^{* *} \\
(0.014)\end{array}$ & $\begin{array}{l}0.038^{* * *} \\
(0.010)\end{array}$ & $\begin{array}{l}-0.000 \\
(0.012)\end{array}$ \\
\hline \multicolumn{7}{|l|}{ Racism } \\
\hline Blacks & $\begin{array}{l}0.266 \\
(2.093)\end{array}$ & $\begin{array}{l}-5.336 \\
(3.482)\end{array}$ & $\begin{array}{l}0.879 \\
(2.710)\end{array}$ & $\begin{array}{l}-2.185 \\
(2.282)\end{array}$ & $\begin{array}{l}-3.524^{*} \\
(1.779)\end{array}$ & $\begin{array}{l}0.446 \\
(1.938)\end{array}$ \\
\hline Hispanics & $\begin{array}{l}0.898 \\
(1.963)\end{array}$ & $\begin{array}{l}-3.554 \\
(2.964)\end{array}$ & $\begin{array}{l}-0.771 \\
(2.592)\end{array}$ & $\begin{array}{l}-4.736^{* *} \\
(2.096)\end{array}$ & $\begin{array}{l}-1.898 \\
(1.795)\end{array}$ & $\begin{array}{l}0.697 \\
(2.060)\end{array}$ \\
\hline Black lives matter & $\begin{array}{l}-2.312 \\
(2.837)\end{array}$ & $\begin{array}{l}-3.132 \\
(4.036)\end{array}$ & $\begin{array}{l}-4.176 \\
(4.025)\end{array}$ & $\begin{array}{l}-6.399^{* *} \\
(3.074)\end{array}$ & $\begin{array}{l}-10.063^{* * *} \\
(2.654)\end{array}$ & $\begin{array}{l}-0.734 \\
(2.832)\end{array}$ \\
\hline \multicolumn{7}{|c|}{ Homophobia and female empowerment } \\
\hline Gays and lesbians & $\begin{array}{l}-1.248 \\
(2.576)\end{array}$ & $\begin{array}{l}-6.823 \\
(4.233)\end{array}$ & $\begin{array}{l}-0.256 \\
(2.904)\end{array}$ & $\begin{array}{l}-1.839 \\
(2.788)\end{array}$ & $\begin{array}{l}-2.876 \\
(2.267)\end{array}$ & $\begin{array}{l}0.619 \\
(2.488)\end{array}$ \\
\hline Transgender & $\begin{array}{l}-1.633 \\
(2.607)\end{array}$ & $\begin{array}{l}-5.967 \\
(3.739)\end{array}$ & $\begin{array}{l}-1.459 \\
(3.034)\end{array}$ & $\begin{array}{l}-1.948 \\
(2.727)\end{array}$ & $\begin{array}{l}-3.608^{*} \\
(2.172)\end{array}$ & $\begin{array}{l}1.027 \\
(2.385)\end{array}$ \\
\hline Feminism & $\begin{array}{l}-0.940 \\
(2.448)\end{array}$ & $\begin{array}{l}-2.627 \\
(3.496)\end{array}$ & $\begin{array}{l}-1.315 \\
(2.942)\end{array}$ & $\begin{array}{l}-1.508 \\
(2.523)\end{array}$ & $\begin{array}{l}-4.124^{*} \\
(2.165)\end{array}$ & $\begin{array}{l}-1.471 \\
(2.457)\end{array}$ \\
\hline \multicolumn{7}{|l|}{ Views on religion } \\
\hline Jews & $\begin{array}{l}3.727^{*} \\
(2.109)\end{array}$ & $\begin{array}{l}-2.362 \\
(3.327)\end{array}$ & $\begin{array}{l}1.957 \\
(2.612)\end{array}$ & $\begin{array}{l}-3.710^{*} \\
(2.144)\end{array}$ & $\begin{array}{l}0.144 \\
(1.879)\end{array}$ & $\begin{array}{l}-2.151 \\
(2.343)\end{array}$ \\
\hline Muslims & $\begin{array}{l}-3.014 \\
(2.451)\end{array}$ & $\begin{array}{l}-1.857 \\
(3.681)\end{array}$ & $\begin{array}{l}-0.679 \\
(2.814)\end{array}$ & $\begin{array}{l}-5.104^{*} \\
(2.603)\end{array}$ & $\begin{array}{l}-5.348^{* *} \\
(2.173)\end{array}$ & $\begin{array}{l}-1.324 \\
(2.867)\end{array}$ \\
\hline \multicolumn{7}{|c|}{ Political candidate support } \\
\hline Hillary Clinton & $\begin{array}{l}-2.673 \\
(2.338)\end{array}$ & $\begin{array}{l}-0.587 \\
(3.306)\end{array}$ & $\begin{array}{l}-1.922 \\
(3.102)\end{array}$ & $\begin{array}{l}-7.846^{* * *} \\
(2.433)\end{array}$ & $\begin{array}{l}-8.142^{\text {*** }} \\
(2.173)\end{array}$ & $\begin{array}{l}-5.851^{*} \\
(3.068)\end{array}$ \\
\hline Donald Trump & $\begin{array}{l}-1.655 \\
(2.640)\end{array}$ & $\begin{array}{l}-0.725 \\
(4.239)\end{array}$ & $\begin{array}{l}0.393 \\
(3.498)\end{array}$ & $\begin{array}{l}17.981^{* * *} \\
(2.723)\end{array}$ & $\begin{array}{l}7.456^{* * *} \\
(2.456)\end{array}$ & $\begin{array}{l}-4.811 \\
(3.779)\end{array}$ \\
\hline
\end{tabular}

$* * * p<0.01, * * p<0.05, * p<0.1$. Dataset: 2016 American National Election Studies. Results are based on 1020 male observations and 1003 female observations. Standard errors are in parentheses. Each row captures the decomposed micro and macroeconomic insecurity results (specified as separate dummy variables) for the outcome listed. Aside from the results pertaining to Distrust and Xenophobia, all estimates are derived using OLS, with the former determined using an ordinal probit specification where average marginal effects are presented. Additional controls include: political identification, income, education level, age, being "born-again", race, foreign/native born, marital status, and whether governor is republican or democrat 
Table 16 Decomposition 1 (females)

\begin{tabular}{|c|c|c|c|c|c|c|}
\hline & \multicolumn{3}{|c|}{ Micro variables } & \multicolumn{3}{|c|}{ Macro variables } \\
\hline & Worsened & Job ins. & Will worsen & Worsened & Is poor & Will worsen \\
\hline Distrust & $\begin{array}{l}0.029 \\
(0.019)\end{array}$ & $\begin{array}{l}-0.013 \\
(0.025)\end{array}$ & $\begin{array}{l}0.058 * * \\
(0.026)\end{array}$ & $\begin{array}{l}0.025 \\
(0.017)\end{array}$ & $\begin{array}{l}0.054 * * * \\
(0.017)\end{array}$ & $\begin{array}{l}0.027 \\
(0.017)\end{array}$ \\
\hline Authoritarianism & $\begin{array}{l}0.143 \\
(0.215)\end{array}$ & $\begin{array}{l}0.238 \\
(0.237)\end{array}$ & $\begin{array}{l}-0.095 \\
(0.276)\end{array}$ & $\begin{array}{l}0.449 * * \\
(0.202)\end{array}$ & $\begin{array}{l}0.506 * * \\
(0.199)\end{array}$ & $\begin{array}{l}0.245 \\
(0.221)\end{array}$ \\
\hline \multicolumn{7}{|c|}{ Xenophobia; Immigration } \\
\hline Decreased a Lot & $\begin{array}{l}0.026 \\
(0.027)\end{array}$ & $\begin{array}{l}-0.047 \\
(0.032)\end{array}$ & $\begin{array}{l}-0.016 \\
(0.034)\end{array}$ & $\begin{array}{l}0.023 \\
(0.028)\end{array}$ & $\begin{array}{l}0.089 * * * \\
(0.026)\end{array}$ & $\begin{array}{l}0.032 \\
(0.027)\end{array}$ \\
\hline Does cultural harm & $\begin{array}{l}-0.001 \\
(0.009)\end{array}$ & $\begin{array}{l}-0.008 \\
(0.011)\end{array}$ & $\begin{array}{l}0.001 \\
(0.011)\end{array}$ & $\begin{array}{l}0.019 * * \\
(0.009)\end{array}$ & $\begin{array}{l}0.031 * * * \\
(0.008)\end{array}$ & $\begin{array}{l}0.000 \\
(0.008)\end{array}$ \\
\hline Is bad for econ. & $\begin{array}{l}0.017 \\
(0.012)\end{array}$ & $\begin{array}{l}-0.022^{*} \\
(0.012)\end{array}$ & $\begin{array}{l}-0.010 \\
(0.012)\end{array}$ & $\begin{array}{l}0.025 * * \\
(0.012)\end{array}$ & $\begin{array}{l}0.034 * * * \\
(0.011)\end{array}$ & $\begin{array}{l}0.012 \\
(0.012)\end{array}$ \\
\hline \multicolumn{7}{|l|}{ Racism } \\
\hline Blacks & $\begin{array}{l}2.030 \\
(2.071)\end{array}$ & $\begin{array}{l}-0.487 \\
(2.487)\end{array}$ & $\begin{array}{l}0.019 \\
(2.924)\end{array}$ & $\begin{array}{l}-0.610 \\
(1.977)\end{array}$ & $\begin{array}{l}-2.624 \\
(1.818)\end{array}$ & $\begin{array}{l}-1.984 \\
(2.140)\end{array}$ \\
\hline Hispanics & $\begin{array}{l}-0.497 \\
(2.055)\end{array}$ & $\begin{array}{l}0.738 \\
(2.882)\end{array}$ & $\begin{array}{l}-0.496 \\
(2.865)\end{array}$ & $\begin{array}{l}-0.618 \\
(2.120)\end{array}$ & $\begin{array}{l}-5.290^{* * *} \\
(1.954)\end{array}$ & $\begin{array}{l}-0.0430 \\
(2.021)\end{array}$ \\
\hline Black lives matter & $\begin{array}{l}-5.474^{* *} \\
(2.628)\end{array}$ & $\begin{array}{l}3.146 \\
(3.308)\end{array}$ & $\begin{array}{l}7.369^{* *} \\
(3.706)\end{array}$ & $\begin{array}{l}-5.474^{* *} \\
(2.673)\end{array}$ & $\begin{array}{l}-2.207 \\
(2.459)\end{array}$ & $\begin{array}{l}-2.516 \\
(2.738)\end{array}$ \\
\hline \multicolumn{7}{|c|}{ Homophobia and female empowerment } \\
\hline Gays and lesbians & $\begin{array}{l}-3.215 \\
(2.360)\end{array}$ & $\begin{array}{l}-0.561 \\
(3.108)\end{array}$ & $\begin{array}{l}2.676 \\
(3.017)\end{array}$ & $\begin{array}{l}-4.814^{*} \\
(2.525)\end{array}$ & $\begin{array}{l}1.117 \\
(2.238)\end{array}$ & $\begin{array}{l}-0.754 \\
(2.242)\end{array}$ \\
\hline Transgender & $\begin{array}{l}-3.215 \\
(2.460)\end{array}$ & $\begin{array}{l}-0.046 \\
(3.219)\end{array}$ & $\begin{array}{l}1.774 \\
(3.196)\end{array}$ & $\begin{array}{l}-5.699^{* *} \\
(2.591)\end{array}$ & $\begin{array}{l}0.727 \\
(2.258)\end{array}$ & $\begin{array}{l}0.834 \\
(2.377)\end{array}$ \\
\hline Feminism & $\begin{array}{l}-7.176^{* * *} \\
(2.310)\end{array}$ & $\begin{array}{l}2.586 \\
(3.185)\end{array}$ & $\begin{array}{l}3.052 \\
(2.856)\end{array}$ & $\begin{array}{l}-3.466 \\
(2.267)\end{array}$ & $\begin{array}{l}0.195 \\
(2.176)\end{array}$ & $\begin{array}{l}1.404 \\
(2.192)\end{array}$ \\
\hline \multicolumn{7}{|l|}{ Views on religion } \\
\hline Jews & $\begin{array}{l}-1.9012 \\
(2.288)\end{array}$ & $\begin{array}{l}-4.715 \\
(3.063)\end{array}$ & $\begin{array}{l}2.989 \\
(2.745)\end{array}$ & $\begin{array}{l}-3.824 \\
(2.364)\end{array}$ & $\begin{array}{l}5.481^{* *} \\
(2.227)\end{array}$ & $\begin{array}{l}-2.222 \\
(2.296)\end{array}$ \\
\hline Muslims & $\begin{array}{l}-4.611^{*} \\
(2.602)\end{array}$ & $\begin{array}{l}-2.223 \\
(3.203)\end{array}$ & $\begin{array}{l}1.289 \\
(3.558)\end{array}$ & $\begin{array}{l}-5.664^{* *} \\
(2.664)\end{array}$ & $\begin{array}{l}-3.580 \\
(2.360)\end{array}$ & $\begin{array}{l}-1.591 \\
(2.695)\end{array}$ \\
\hline \multicolumn{7}{|c|}{ Political candidate support } \\
\hline Hillary Clinton & $\begin{array}{l}-6.733^{* * *} \\
(2.515)\end{array}$ & $\begin{array}{l}5.446^{*} \\
(3.234)\end{array}$ & $\begin{array}{l}0.447 \\
(3.138)\end{array}$ & $\begin{array}{l}-8.096^{* * *} \\
(2.472)\end{array}$ & $\begin{array}{l}-10.557^{* * *} \\
(2.337)\end{array}$ & $\begin{array}{l}-7.510^{* * * *} \\
(2.384)\end{array}$ \\
\hline Donald Trump & $\begin{array}{l}7.627 * * * \\
(2.493)\end{array}$ & $\begin{array}{l}-4.929 \\
(3.298)\end{array}$ & $\begin{array}{l}-1.824 \\
(3.510)\end{array}$ & $\begin{array}{l}10.624 * * * \\
(2.755)\end{array}$ & $\begin{array}{l}9.603 * * * \\
(2.530)\end{array}$ & $\begin{array}{l}-1.887 \\
(2.687)\end{array}$ \\
\hline
\end{tabular}

$* * * p<0.01, * * p<0.05, * p<0.1$. Dataset: 2016 American National Election Studies. Results are based on 1020 male observations and 1003 female observations. Standard errors are in parentheses. Each row captures the decomposed micro and macroeconomic insecurity results (specified as separate dummy variables) for the outcome listed. Aside from the results pertaining to Distrust and Xenophobia, all estimates are derived using OLS, with the former determined using an ordinal probit specification where average marginal effects are presented. Additional controls include: political identification, income, education level, age, being "born-again", race, foreign/native born, marital status, and whether governor is republican or democrat 
Table 17 Decomposition 2 (males)

\begin{tabular}{|c|c|c|c|c|c|c|}
\hline & \multicolumn{3}{|c|}{ Respondent's financial position } & \multicolumn{3}{|c|}{ The macro economy } \\
\hline & Worsened & Will worsen & Both & Worsened & Will worsen & Both \\
\hline Distrust & $\begin{array}{l}0.043 * \\
(0.025)\end{array}$ & $\begin{array}{l}-0.030 \\
(0.025)\end{array}$ & $\begin{array}{l}0.155^{* * *} \\
(0.053)\end{array}$ & $\begin{array}{l}0.036 \\
(0.027)\end{array}$ & $\begin{array}{l}0.017 \\
(0.022)\end{array}$ & $\begin{array}{l}0.098^{* *} \\
(0.044)\end{array}$ \\
\hline Authoritarianism & $\begin{array}{l}0.087 \\
(0.242)\end{array}$ & $\begin{array}{l}1.018^{* * *} \\
(0.336)\end{array}$ & $\begin{array}{l}-0.395 \\
(0.370)\end{array}$ & $\begin{array}{l}0.872^{* * *} \\
(0.225)\end{array}$ & $\begin{array}{l}-0.062 \\
(0.306)\end{array}$ & $\begin{array}{l}0.832^{* *} \\
(0.323)\end{array}$ \\
\hline \multicolumn{7}{|c|}{ Xenophobia; Immigration } \\
\hline Decreased a lot & $\begin{array}{l}-0.011 \\
(0.033)\end{array}$ & $\begin{array}{l}0.057 \\
(0.058)\end{array}$ & $\begin{array}{l}0.039 \\
(0.048)\end{array}$ & $\begin{array}{l}0.168^{* * *} \\
(0.043)\end{array}$ & $\begin{array}{l}0.048 \\
(0.033)\end{array}$ & $\begin{array}{l}0.231^{* * *} \\
(0.058)\end{array}$ \\
\hline Does cultural harm & $\begin{array}{l}-0.013 \\
(0.008)\end{array}$ & $\begin{array}{l}0.060^{* *} \\
(0.028)\end{array}$ & $\begin{array}{l}0.001 \\
(0.018)\end{array}$ & $\begin{array}{l}0.064^{* * *} \\
(0.017)\end{array}$ & $\begin{array}{l}0.003 \\
(0.010)\end{array}$ & $\begin{array}{l}0.039^{* *} \\
(0.018)\end{array}$ \\
\hline Is bad for econ. & $\begin{array}{l}0.002 \\
(0.013)\end{array}$ & $\begin{array}{l}0.051^{*} \\
(0.030)\end{array}$ & $\begin{array}{l}-0.018 \\
(0.016)\end{array}$ & $\begin{array}{l}0.065^{* * *} \\
(0.020)\end{array}$ & $\begin{array}{l}0.013 \\
(0.013)\end{array}$ & $\begin{array}{l}0.037 \\
(0.023)\end{array}$ \\
\hline \multicolumn{7}{|l|}{ Racism } \\
\hline Blacks & $\begin{array}{l}0.285 \\
(2.114)\end{array}$ & $\begin{array}{l}2.700 \\
(3.208)\end{array}$ & $\begin{array}{l}-3.608 \\
(4.473)\end{array}$ & $\begin{array}{l}-4.232 \\
(2.785)\end{array}$ & $\begin{array}{l}-0.281 \\
(2.278)\end{array}$ & $\begin{array}{l}-2.464 \\
(3.059)\end{array}$ \\
\hline Hispanics & $\begin{array}{l}1.525 \\
(2.104)\end{array}$ & $\begin{array}{l}1.848 \\
(2.976)\end{array}$ & $\begin{array}{l}-4.302 \\
(4.255)\end{array}$ & $\begin{array}{l}-6.251^{* * *} \\
(2.352)\end{array}$ & $\begin{array}{l}-0.108 \\
(2.500)\end{array}$ & $\begin{array}{l}-3.879 \\
(3.119)\end{array}$ \\
\hline Black lives matter & $\begin{array}{l}-3.369 \\
(3.003)\end{array}$ & $\begin{array}{l}-4.849 \\
(5.456)\end{array}$ & $\begin{array}{l}-9.892 \\
(6.111)\end{array}$ & $\begin{array}{l}-11.283^{* * *} \\
(3.384)\end{array}$ & $\begin{array}{l}-2.236 \\
(3.524)\end{array}$ & $\begin{array}{l}-10.480^{* *} \\
(4.341)\end{array}$ \\
\hline \multicolumn{7}{|c|}{ Homophobia and female empowerment } \\
\hline Gays and lesbians & $\begin{array}{l}-2.949 \\
(2.785)\end{array}$ & $\begin{array}{l}-2.165 \\
(3.125)\end{array}$ & $\begin{array}{l}-2.900 \\
(4.471)\end{array}$ & $\begin{array}{l}-2.466 \\
(3.201)\end{array}$ & $\begin{array}{l}1.218 \\
(2.876)\end{array}$ & $\begin{array}{l}-3.202 \\
(4.038)\end{array}$ \\
\hline Transgender & $\begin{array}{l}-2.863 \\
(2.763)\end{array}$ & $\begin{array}{l}-2.876 \\
(3.291)\end{array}$ & $\begin{array}{l}-5.181 \\
(5.004)\end{array}$ & $\begin{array}{l}-4.867 \\
(3.160)\end{array}$ & $\begin{array}{l}-1.114 \\
(2.865)\end{array}$ & $\begin{array}{l}-0.128 \\
(3.321)\end{array}$ \\
\hline Feminism & $\begin{array}{l}-1.067 \\
(2.696)\end{array}$ & $\begin{array}{l}-0.177 \\
(3.744)\end{array}$ & $\begin{array}{l}-5.324 \\
(4.330)\end{array}$ & $\begin{array}{l}-2.587 \\
(2.723)\end{array}$ & $\begin{array}{l}-0.675 \\
(3.024)\end{array}$ & $\begin{array}{l}-5.892 \\
(3.650)\end{array}$ \\
\hline \multicolumn{7}{|l|}{ Views on religion } \\
\hline Jews & $\begin{array}{l}2.544 \\
(2.110)\end{array}$ & $\begin{array}{l}-1.055 \\
(3.104)\end{array}$ & $\begin{array}{l}7.330^{*} \\
(3.926)\end{array}$ & $\begin{array}{l}-5.839^{* *} \\
(2.486)\end{array}$ & $\begin{array}{l}-5.352^{*} \\
(2.969)\end{array}$ & $\begin{array}{l}-2.088 \\
(2.630)\end{array}$ \\
\hline Muslims & $\begin{array}{l}-3.915 \\
(2.614)\end{array}$ & $\begin{array}{l}-2.165 \\
(3.175)\end{array}$ & $\begin{array}{l}-4.694 \\
(4.819)\end{array}$ & $\begin{array}{l}-8.805^{* * *} \\
(3.058)\end{array}$ & $\begin{array}{l}-3.729 \\
(3.787)\end{array}$ & $\begin{array}{l}-6.375^{* *} \\
(3.237)\end{array}$ \\
\hline \multicolumn{7}{|c|}{ Political candidate support } \\
\hline Hillary Clinton & $\begin{array}{l}-2.347 \\
(2.414)\end{array}$ & $\begin{array}{l}-0.185 \\
(3.705)\end{array}$ & $\begin{array}{l}-8.910^{* *} \\
(4.350)\end{array}$ & $\begin{array}{l}-12.478^{* * *} \\
(2.586)\end{array}$ & $\begin{array}{l}-7.845^{*} \\
(4.098)\end{array}$ & $\begin{array}{l}-15.508^{* * *} \\
(3.740)\end{array}$ \\
\hline Donald Trump & $\begin{array}{l}-1.236 \\
(2.760)\end{array}$ & $\begin{array}{l}1.393 \\
(4.197)\end{array}$ & $\begin{array}{l}0.022 \\
(5.315)\end{array}$ & $\begin{array}{l}23.667^{* * *} \\
(2.855)\end{array}$ & $\begin{array}{l}-0.760 \\
(5.045)\end{array}$ & $\begin{array}{l}12.378^{* * *} \\
(4.316)\end{array}$ \\
\hline
\end{tabular}

$* * * p<0.01, * * p<0.05, * p<0.1$. Dataset: 2016 American National Election Studies. Results are based on 1020 male observations and 1003 female observations. Standard errors are in parentheses. Each row captures the results regarding the respondent's perception of the past and future state of their own financial well-being, along with that of the economy; the reference category is both an improvement from 12 months ago, and further improvement over the next 12 months. Aside from the results pertaining to Distrust and Xenophobia, all estimates are derived using OLS, with the former determined using an ordinal probit specification where average marginal effects are presented. Additional controls include: political identification, income, education level, age, being "born-again", race, foreign/native born, marital status, and whether governor is republican or democrat 
Table 18 Decomposition 2 (females)

\begin{tabular}{|c|c|c|c|c|c|c|}
\hline & \multicolumn{3}{|c|}{ Respondent's financial position } & \multicolumn{3}{|c|}{ The macro economy } \\
\hline & Worsened & Will worsen & Both & Worsened & Will worsen & Both \\
\hline \multirow[t]{2}{*}{ Distrust } & $0.040^{* *}$ & $0.081^{* *}$ & $0.097^{* *}$ & $0.049^{* *}$ & $0.034^{*}$ & $0.074^{* * *}$ \\
\hline & $(0.019)$ & $(0.036)$ & $(0.041)$ & $(0.021)$ & $(0.020)$ & $(0.027)$ \\
\hline \multirow[t]{2}{*}{ Authoritarianism } & 0.259 & -0.007 & 0.295 & $0.874^{* * *}$ & $0.605^{* *}$ & $0.696^{* *}$ \\
\hline & $(0.225)$ & $(0.316)$ & $(0.431)$ & $(0.213)$ & $(0.285)$ & $(0.300)$ \\
\hline \multicolumn{7}{|c|}{ Xenophobia; Immigration } \\
\hline \multirow[t]{2}{*}{ Decreased a lot } & 0.021 & -0.028 & 0.061 & $0.076^{* *}$ & $0.066^{*}$ & 0.061 \\
\hline & $(0.026)$ & $(0.039)$ & $(0.058)$ & $(0.034)$ & $(0.035)$ & $(0.042)$ \\
\hline \multirow[t]{2}{*}{ Does cultural harm } & -0.001 & -0.003 & 0.019 & $0.034^{* * *}$ & 0.005 & $0.029^{* *}$ \\
\hline & $(0.009)$ & $(0.013)$ & $(0.020)$ & $(0.012)$ & $(0.010)$ & $(0.013)$ \\
\hline \multirow[t]{2}{*}{ Is bad for econ. } & 0.013 & -0.014 & 0.024 & $0.042^{* * *}$ & 0.018 & $0.044^{* *}$ \\
\hline & $(0.013)$ & $(0.012)$ & $(0.025)$ & $(0.014)$ & $(0.015)$ & $(0.021)$ \\
\hline \multicolumn{7}{|l|}{ Racism } \\
\hline \multirow[t]{2}{*}{ Blacks } & 3.136 & 3.387 & -2.173 & -2.344 & -3.139 & -2.674 \\
\hline & $(2.116)$ & $(3.816)$ & $(3.776)$ & $(2.109)$ & $(2.593)$ & $(3.072)$ \\
\hline \multirow[t]{2}{*}{ Hispanics } & 0.512 & 2.920 & -6.083 & -2.936 & -0.753 & -2.101 \\
\hline & $(2.136)$ & $(3.499)$ & $(4.148)$ & $(2.320)$ & $(2.357)$ & $(2.999)$ \\
\hline \multirow[t]{2}{*}{ Black lives matter } & -4.385 & $9.211^{*}$ & -0.220 & $-6.987^{* *}$ & -3.817 & $-7.580^{*}$ \\
\hline & $(2.737)$ & $(4.779)$ & $(4.788)$ & $(2.756)$ & $(3.198)$ & $(3.934)$ \\
\hline \multicolumn{7}{|c|}{ Homophobia and female empowerment } \\
\hline \multirow[t]{2}{*}{ Gays and lesbians } & -3.109 & 2.876 & -0.280 & -4.230 & -0.423 & -5.343 \\
\hline & $(2.527)$ & $(4.061)$ & (3.983) & $(2.664)$ & $(2.563)$ & $(3.547)$ \\
\hline \multirow[t]{2}{*}{ Transgender } & -2.186 & 3.933 & -3.123 & $-6.143^{* *}$ & -0.185 & -3.639 \\
\hline & $(2.537)$ & $(4.301)$ & (4.184) & $(2.911)$ & $(2.550)$ & $(3.779)$ \\
\hline \multirow[t]{2}{*}{ Feminism } & $-6.400^{* * *}$ & 3.673 & -4.417 & $-4.601^{*}$ & -0.571 & -0.291 \\
\hline & $(2.371)$ & $(3.667)$ & (3.663) & $(2.524)$ & $(2.592)$ & $(3.430)$ \\
\hline \multicolumn{7}{|l|}{ Views on religion } \\
\hline \multirow[t]{2}{*}{ Jews } & -0.377 & $7.061^{* *}$ & -0.623 & -1.175 & -0.748 & -4.747 \\
\hline & $(2.329)$ & $(3.368)$ & (3.930) & $(2.349)$ & $(2.403)$ & $(4.026)$ \\
\hline \multirow[t]{2}{*}{ Muslims } & $-4.546^{*}$ & 3.101 & -6.968 & $-7.780^{* * *}$ & -2.729 & $-8.073^{*}$ \\
\hline & $(2.522)$ & $(4.509)$ & $(5.026)$ & $(2.748)$ & $(2.558)$ & $(4.634)$ \\
\hline \multicolumn{7}{|c|}{ Political candidate support } \\
\hline \multirow[t]{2}{*}{ Hillary Clinton } & $-8.426^{* * *}$ & -3.306 & -7.459 & $-14.808^{* * *}$ & $-12.483^{* * *}$ & $-16.584^{* * *}$ \\
\hline & $(2.604)$ & $(3.561)$ & (4.735) & $(2.844)$ & $(2.532)$ & (4.017) \\
\hline \multirow[t]{2}{*}{ Donald Trump } & $8.012^{* * *}$ & -0.937 & $9.367^{*}$ & $18.208^{* * *}$ & 4.830 & $7.860^{* *}$ \\
\hline & $(2.525)$ & (3.901) & $(5.323)$ & $(2.835)$ & (3.204) & (3.816) \\
\hline
\end{tabular}

$* * * p<0.01, * * p<0.05, * p<0.1$. Dataset: 2016 American National Election Studies. Results are based on 1020 male observations and 1003 female observations. Standard errors are in parentheses. Each row captures the results regarding the respondent's perception of the past and future state of their own financial well-being, along with that of the economy; the reference category is both an improvement from 12 months ago, and further improvement over the next 12 months. Aside from the results pertaining to Distrust and Xenophobia, all estimates are derived using OLS, with the former determined using an ordinal probit specification where average marginal effects are presented. Additional controls include: political identification, income, education level, age, being "born-again", race, foreign/native born, marital status, and whether governor is republican or democrat. 


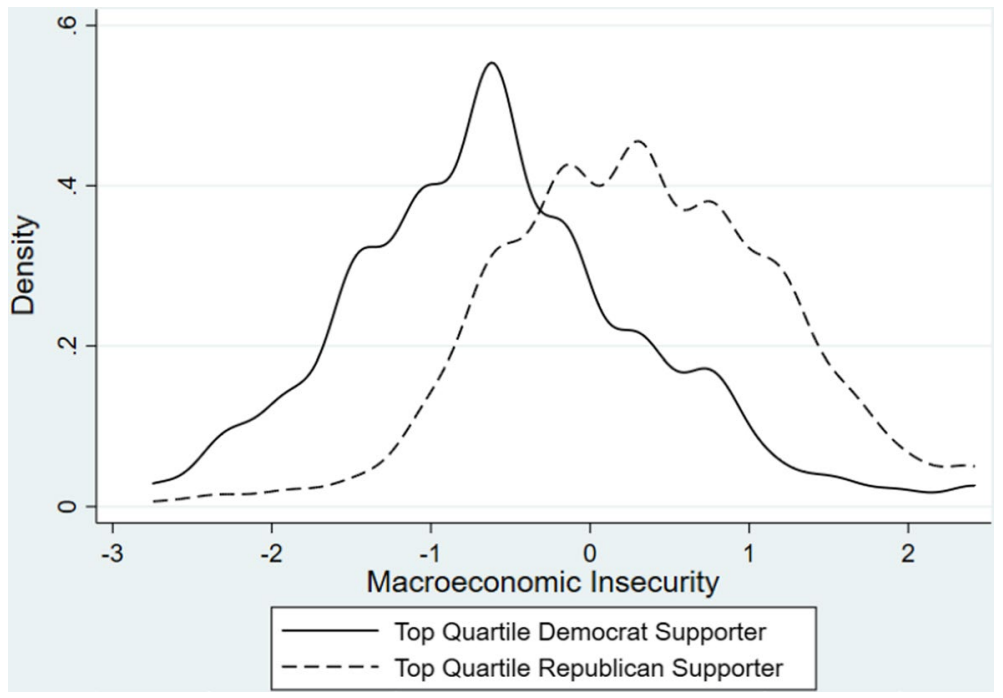

Fig. 7 Kernel density plot of macroeconomic insecurity based on political support

\section{References}

Adorno, T. W., Frenkel-Brunswik, E., Levinson, D. J., \& Sanford, R. N. (1950). The authoritarian personality. New York: Harper and Row.

Anderson, B. (1983). Imagined communities: Reflections on the origin and spread of nationalism. New York: Verso.

Anderson, E. (2018). The great reversal. Progressive Review, 25(2), 202-213.

Armour, P., Burkhauser, R. V., \& Larrimore, J. (2016). Using the pareto distribution to improve estimates of topcoded earnings. Economic Inquiry, 54(2), 1263-1273.

Azzimonti, M. (2018). Partisan conflict and private investment. Journal of Monetary Economics, 93(C), 114-131.

Baccini, L., \& Weymouth, S. (2021). Gone for good: Deindustrialization, white voter backlash, and US presidential voting. American Political Science Review, 115(2), 550-567.

Bohnet, I., \& Zeckhauser, R. (2004). Trust, risk and betrayal. Journal of Economic Behavior and Organization, 55(4), 467-484.

Bossert, W., Clark, A.E., D’Ambrosio, C., \& Lepinteur, A. (2019). Economic insecurity and the rise of the right. CEP Discussion Paper 1659, Centre for Economic Performance, London School of Economics and Political Science

Dallman, M. F., Pecoraro, N., Akana, S. F., la Fleur, S. E., Gomez, F., Houshyar, H., et al. (2003). Chronic stress and obesity: A new view of "comfort food". Proceedings of the National Academy of Sciences of the United States of America, 100(20), 11696-11791.

Feldman, S., \& Stenner, K. (1997). Perceived threat and authoritarianism. Political Psychology, 18(4), $741-770$.

Galston, W. A. (2017). The 2016 US election: The populist moment. Journal of Democracy, 28(2), 21-33.

Gasiorowski, M. J. (1990). The political regimes project. Studies in Comparative International Development, 25(1), 109-125.

Gidron, N., \& Hall, P. A. (2017). The politics of social status: Economic and cultural roots of the populist right. The British Journal of Sociology, 68(S1), S57-S84.

Gillitzer, C., \& Prasad, N. (2018). The effect of consumer sentiment on consumption: Cross-sectional evidence from elections. American Economic Journal: Macroeconomics, 10(4), 234-269.

Grossmann, M., \& Thaler, D. (2018). Mass-elite divides in aversion to social change and support for Donald Trump. American Politics Research, 46(5), 753-784.

Guiso, L., Herrera, H., Morelli, M., Sonno, T. (2017). Demand and supply of populism. EIEF Working Papers Series 1703, Einaudi Institute for Economics and Finance (EIEF) 
Hacker, J. S. (2006). The great risk shift. New York: Oxford University Press.

Hacker, J. S., Huber, G. A., Nichols, A., Rehm, P., Schlesinger, M., Valletta, R., \& Stuart, C. (2014). The economic security index: A new measure for research and policy analysis. The Review of Income and Wealth, 60(S1), S5-S32.

Hetherington, M., \& Suhay, E. (2011). Authoritarianism, threat, and American's support for the war on terror. American Journal of Political Science, 55(3), 546-560.

Hetherington, M., \& Weiler, J. (2009). Authoritarianism and polarization in American politics. New York: Cambridge University Press.

Howden, L. M., \& Meyer, J. A. (2011). Age and sex composition: 2010. Census Bureau: U.S.

Inglehart, R., \& Norris, P. (2016). Trump, Brexit, and the Rise of Populism: Economic Have-Nots and Cultural Backlash. HKS Faculty Research Working Paper Series 16-026, Harvard Kennedy School (HKS)

Inglehart, R., \& Norris, P. (2017). Trump and the populist authoritarian parties: The silent revolution in reverse. Perspectives on Politics, 15(2), 184-194.

Jacobson, G. C. (2017). The Triumph of polarized partisanship in 2016: Donald Trump's improbable victory. Political Science Quarterly, 132(1), 9-41.

Kamarch, E. (2012) Are You Better Off Than You Were 4 Years Ago? WBUR

Keay, D. (1987). AIDS, education, and the year 2000: An interview with margaret thatcher. Woman's Own pp. $8-10$

Kinder, D. R., \& Kiewiet, D. R. (1979). Economic discontent and political behavior: The role of personal grievances and collective economic judgements in congressional voting. American Journal of Political Science, 23(3), 495-527.

Kinder, D. R., \& Kiewiet, D. R. (1981). Sociotropic politics: The American case. British Journal of Political Science, 11(2), 129-161.

Koehler, J. J., \& Gershoff, A. D. (2003). Betrayal aversion: When agents of protection become agents of harm. Organizational Behavior and Human Decision Processes, 90(2), 244-261.

Lewis-Beck, M. S., \& Stegmaier, M. (2013). The VP-function revisited: A survey of the literature on vote and popularity functions after over 40 years. Public Choice, 157(3/4), 367-385.

Linz, J. (1964). An authoritarian regime: Spain. In E. Allardt \& Y. Littunen (Eds.), Cleavages, ideologies and party systems, westermarck society. Helsinki: Finland.

Lockerbie, B. (2006). Economics and Politics: Egocentric or Sociotropic? The American Review of Politics, 27, 191-208.

Margalit, Y. (2019). Economic insecurity and the causes of populism. Reconsidered. Journal of Economic Perspectives, 33(4), 152-170.

McCarty, N., Poole, K. T., \& Rosenthal, H. (2006). Polarized America: The dance of ideology and unequal riches. Cambridge: The MIT PRess.

Mudde, C. (2007). Populist radical right parties in Europe. Cambridge: Cambridge University Press.

Mughan, A., \& Lacy, D. (2002). Economic performance, job insecurity and electoral choice. British Journal of Political Science, 32(3), 513-533.

Mughan, A., Bean, C., \& McAllister, I. (2004) Economic globalization, job insecurity and the populist reaction. Electoral Studies, pp. 617-633

Mutz, D. C. (2018). Status threat, not economic hardship, explains the 2016 presidential vote. Proceedings of the National Academy of Sciences, 115(19), E4330-E4339.

Osberg, L. (1998). Economic insecurity (Discussion paper No. 88). Social Policy Research Center, Sydney, Australia

Osberg, L. (2015). How should one measure economic insecurity? OECD statistics working papers 2015/1, OECD Publishing

Przeworski, A. (1991). Democracy and the market: Political and economic reforms in Eastern Europe and Latin America. Cambridge: Cambridge University Press.

Quandt, R. (1966). Old and new methods of estimation and the pareto distribution. Metrika, 10, 55-82.

Saez, E. (2000). Using elasticities to derive optimal income tax rates. Review of Economic Studies, 68, 205-229.

Schaffner, B. F., MacWilliams, M., \& Nteta, T. (2018). Understanding white polarization in the 2016 vote for president: The sobering role of racism and sexism. Political Science Quarterly, 133(1), 9-34.

Stansfeld, S., Fuhrer, R., Shipley, M., \& Marmot, M. (2002). Psychological distress as a risk factor for coronary heart disease in the Whitehall II Study. International Journal of Epidemiology, 31(1), 248-255.

Steenvoorden, E. H., \& Wright, M. (2019). Political shades of 'we': Sociotropic uncertainty and multiple political identification in europe. European Societies, 21(1), 4-32.

Stenner, K. (2005). The authoritarian dynamic. New York: Cambridge University Press. 
Stravynski, A., \& Boyer, R. (2001). Loneliness in relation to suicide ideation and parasuicide: A population-wide study. Suicide and Life-Threatening Behavior, 31(1), 32-40.

Tella, R. D., \& Rotemberg, J. J. (2018). Populism and the return of the "Paranoid Style": Some evidence and a simple model of demand for incompetence as insurance against elite betrayal. Journal of Comparative Economics, 46(4), 988-1005.

Tormos, R. (2019). Measuring personal economic hardship and its impact on political trust during the great recession. Social Indicators Research, 144(3), 1209-1232.

Ulrich-Schad, J. D., \& Duncan, C. M. (2018). People and places left behind: Work, culture and politics in the rural United States. The Journal of Peasant Studies, 45(1), 59-79.

Van Green, T., \& Tyson, A. (2020) 5 facts about partisan reactions to COVID-19 in the U.S. https://www. pewresearch.org/fact-tank/2020/04/02/5-facts-about-partisan-reactions-to-covid-19-in-the-u-s/, accessed: 2020-04-16

Watson, B., \& Osberg, L. (2017). Healing and/or breaking? The mental health implications of repeated economic insecurity. Social Science and Medicine, 188, 119-127.

Wroe, A. (2014). Political trust and job insecurity in 18 European polities. Journal of Trust Research, 4(2), 90-112.

Wroe, A. (2016). Economic insecurity and political trust in the United States. American Politics Research, 44(1), 131-163.

Publisher's Note Springer Nature remains neutral with regard to jurisdictional claims in published maps and institutional affiliations. 